\title{
The Good, the Bad, and the Ugly: Neutrophils, Angiogenesis, and Cancer
}

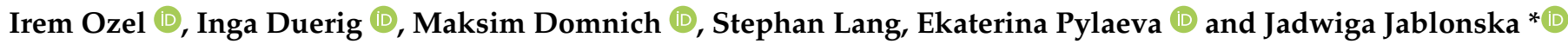

check for updates

Citation: Ozel, I.; Duerig, I.; Domnich, M.; Lang, S.; Pylaeva, E.; Jablonska, J. The Good, the Bad, and the Ugly: Neutrophils, Angiogenesis, and Cancer. Cancers 2022, 14, 536.

https://doi.org/10.3390/ cancers14030536

Academic Editor: Enrico Giraudo

Received: 22 December 2021

Accepted: 17 January 2022

Published: 21 January 2022

Publisher's Note: MDPI stays neutral with regard to jurisdictional claims in published maps and institutional affiliations.

Copyright: () 2022 by the authors Licensee MDPI, Basel, Switzerland. This article is an open access article distributed under the terms and conditions of the Creative Commons Attribution (CC BY) license (https:/ / creativecommons.org/licenses/by/ $4.0 /)$.
Department of Otorhinolaryngology, University Hospital Essen, University Duisburg-Essen, 45147 Essen, Germany; irem.oezel@uk-essen.de (I.O.); inga.duerig@uk-essen.de (I.D.); maksim.domnich@uk-essen.de (M.D.); stephan.lang@uk-essen.de (S.L.); ekaterina.pylaeva@uk-essen.de (E.P.)

* Correspondence: jadwiga.jablonska@uk-essen.de

Simple Summary: Tumor angiogenesis is one of the most critical steps in the progression of cancer. Owing to its fundamental role in tumor growth and metastasis, tumor angiogenesis is accepted to be a limiting factor and considered a powerful therapeutic target. Neutrophils contribute to the tumor progression via multiple mechanisms, ranging from the direct support of tumor cell survival to the immunosuppression. A strong body of evidence suggests that neutrophils also play a prominent role in tumor angiogenesis. In this manuscript, we provide an up do date review of the pro-angiogenic functions of neutrophils, in the context of cancer, and discuss the possibility of therapeutically targeting the pro-angiogenic capacity of these cells in cancer patients.

\begin{abstract}
Angiogenesis, the formation of new blood vessels from already existing vasculature, is tightly regulated by pro- and anti-angiogenic stimuli and occurs under both physiological and pathological conditions. Tumor angiogenesis is central for tumor development, and an "angiogenic switch" could be initiated by multiple immune cells, such as neutrophils. Tumor-associated neutrophils promote tumor angiogenesis by the release of both conventional and non-conventional pro-angiogenic factors. Therefore, neutrophil-mediated tumor angiogenesis should be taken into consideration in the design of novel anti-cancer therapy. This review recapitulates the complex role of neutrophils in tumor angiogenesis and summarizes neutrophil-derived pro-angiogenic factors and mechanisms regulating angiogenic activity of tumor-associated neutrophils. Moreover, it provides up-to-date information about neutrophil-targeting therapy, complementary to anti-angiogenic treatment.
\end{abstract}

Keywords: tumor vasculature; neutrophils; cancer; tumor angiogenesis

\section{Introduction}

The functional vascular system, in complex a multicellular organism, is a very vital asset for survival. The network of blood vessels nurtures all the tissues by supplying oxygen and nutrients, as well as providing gateways for immune surveillance [1,2]. In the early development of the embryo, mesoderm-derived endothelial precursor cells (termed angioblasts) constituted vasculogenesis. In later stages of embryonic development, the tree-like structure of blood vessels were generated from this initial vasculature, in a process called "angiogenesis" [3]. Although the new vessel formation occurs mainly during the embryonic development, angiogenesis also takes place in the adult organism and plays a crucial role in physiological conditions, such as wound healing, placenta formation, and menstrual cycles [3]. Next to physiological angiogenesis, abnormal development of new blood vessels occurs in multiple pathological conditions, such as cancer. Tumor angiogenesis is essential for cancer progression because tumors cannot grow beyond $1 \mathrm{~mm}^{3}$ without sufficient blood supply [4]. Moreover, the spread of tumor cells is strongly dependent on functional vasculature [5]. Therefore, tumor cells release factors that modulate the activity of immune cells, including neutrophils, to support their pro-angiogenic activity. Herein, 
we recapitulate the contribution of neutrophils to the cancer angiogenesis and discuss their potential complementary role in the anti-angiogenic cancer immunotherapy.

\section{Physiological Angiogenesis vs. Tumor Angiogenesis}

Angiogenesis is the process of new blood vessel formation from already existing vasculature. The capillary of blood vessels consists of an endothelial cell (EC) monolayer, surrounded by the basal membrane and pericytes [1]. In the steady state, endothelial cells are non-proliferating and quiescent, and their activation is strongly coordinated by pro-angiogenic signals [6]. These pro-angiogenic signals occasionally appear, along with the demand for nutrients or oxygen in hypoxic and nutrient-deprived tissues [7]. In response to pro-angiogenic signals, two conventional mechanisms of angiogenesis are known: sprouting angiogenesis (SA) and intussusceptive angiogenesis (IA), which was discovered later [8]. SA contributes to vascular growth via the formation of sprouts from existing vessels, whereas IA is characterized by the splitting of already existing vessels into new ones [9]. IA is a relatively faster mechanism than SA, and it is mainly responsible for vascular remodeling [8]. SA and IA are reviewed in detail elsewhere [8,10].

In physiological conditions, angiogenesis is a strongly controlled process, which relies on complex interactions among endothelial cells, pericytes, vascular smooth muscle cells, and immune cells [1]. The initiation of angiogenesis is mediated by pro-angiogenic factors that are released from ischemic/hypoxic or nutrient-deprived tissues. Classical pro-angiogenic factors are: vascular endothelial growth (VEGFs), fibroblast growth (FGFs), platelet derived growth (PDGFs), angiopoietins (ANGs), hepatocyte growth (HGF), insulinlike growth (IGFs), tumor necrosis (TNF) [11], and interleukin 6 (IL-6) [12]. Those factors stimulate endothelial cells to form tip and stalk cells and support their migration towards angiogenic stimuli [12]. Tip cells are activated ECs that secrete the enzymes responsible for the degradation of extracellular matrix (ECM), such as matrix metalloproteinase-9 (MMP-9). Stalk cells show a highly proliferative profile and are responsible for the elongation of the sprout. These cells line the wall of sprouts and form the lumen that enable the blood flow [1].

Among many pathways, the VEGF-VEGFR axis is the most studied signaling pathway in angiogenesis [13]. In addition, numerous non-classical pro-angiogenic signals and auxiliary molecules have been identified, such as erythropoietin (EPO) [14], apelin [15], coagulation factor XIII (FXIII) [16], pro-inflammatory cytokines [17-23], or exosomes [24-27]. Anti-angiogenic factors, on the other hand, such as thrombospondin-1 [28], endostatin [29], tumstatin [30], interferon- $\alpha($ IFN- $\alpha)$ [31], or IFN- $\beta$ [32] limit the angiogenesis by maintaining the quiescent state of endothelial cells. The balance between pro- and anti-angiogenic factors is crucial for normal, functional vessel formation; therefore, its deregulation results in pathology and contributes to the progression of diseases, such as cancer.

Malignant cells, similar to normal cells, need oxygen and nutrients in order to proliferate. In its early stage, cancer grows in an avascular mode that is sufficient for cell proliferation and survival. At later stages, tumor cells become hypoxic and upregulate hypoxia-inducible factor-1 (HIF-1) [33], which supports the expression of pro-angiogenic molecules by binding to their promotors [34]. As the tumor grows and creates an uncontrolled proliferating cell mass, it becomes increasingly dependent on the vasculature. The importance of angiogenesis for cancer development was first proposed by Judah Folkman [4] and is now generally accepted [4,35-40]. With the increasing nutrient and oxygen demand, along with the hypoxic microenvironment of a newly growing tumor, expression of pro-angiogenic factors is accelerated. This shift of angiogenic balance is called "angiogenic switch".

Tumor vasculature can be established through conventional angiogenesis mechanisms (SA and IA), as well as via vascular mimicry or blood vessel co-option [10]. Two latter mechanisms (occasionally called non-angiogenic mechanisms) are limited to pathological conditions and do not depend on pro-angiogenic factors [13]. In vessel co-option, pre-existing tissue vessels are hijacked and incorporated into the tumor [13]. In vascular 
mimicry, tumor cells behave like ECs and form non-endothelial vessels [8]. Opposite to physiological angiogenesis, where the activity of ECs is tightly controlled, tumor angiogenesis is strongly accelerated through the constant pro-angiogenic signaling and results in the formation of disordered, partly non-functional vasculature. Tumor blood vessels consist of tumor endothelial cells (TECs), which are different from normal ECs by morphology, gene expression, and metabolism [41]. TECs are structurally abnormal, have weak intercellular junctions, and show increased proliferation and migration, in response to angiogenic signaling [41]. Moreover, it has been suggested that these cells are resistant to senescence [41].

Tumor cells autonomously produce pro-angiogenic signals; however, they could also prime immune cells, such as neutrophils, to further promote angiogenesis [41]. Tumorassociated inflammation also has an important role in tumor angiogenesis and progression [42]. In response to hypoxia, the expression of pro-inflammatory molecules is upregulated in TECs [43], leading to the recruitment and activation of inflammatory cells, such as macrophages and neutrophils, that contribute to the tumor angiogenesis.

\section{Neutrophils in Cancer}

Neutrophils, as the most abundant leukocytes in human blood circulation, ranging between 50 and 70 percent (10-25 percent in mice) [44], are essential players in innate immunity and inflammatory responses. Nearly every day, new neutrophils $\left(10^{11}\right.$ cells in human) are produced in the bone marrow, in a process called granulopoiesis [45]. Neutrophils were initially believed to be terminally differentiated, homogenous, and short-lived cells; however, recent studies challenged this hypothesis and showed that neutrophils have high diversity and plasticity, with regard to functions [46-55]. Notably, growing tumors strongly affect the development and activity of neutrophils via a plethora of released growth factors and cytokines [46].

Tumor-Associated Neutrophils

The role of neutrophils in cancer is still controversial. High numbers of immature myeloid cells in the blood, including neutrophils (neutrophilia), is a frequently seen phenomenon in cancer patients, as well as in tumor-bearing mice [46,56,57]. Neutrophils efficiently infiltrate to tumors (tumor-associated neutrophils, TANs) and constitute a very important component of the tumor microenvironment (TME) [58,59]. In numerous preclinical and clinical studies, TANs have been shown to participate in malignant transformation, anti-tumoral immunity, and angiogenesis [56,60-63]. Moreover, an increased neutrophil-to-lymphocyte ratio (NLR) is now a well-recognized predictive factor for the progression of many cancer types [64-68].

Strong body of evidence suggests that tumor cells produce growth factors (IL-3, GMCSF, and G-CSF) or inflammatory cytokines (IL-1 $\beta$, IL-6, IL-17 and TNF- $\alpha$ ) to induce neutrophil production and support their survival $[69,70]$. Neutrophil-attracting chemokines, such as CXCL1, CXCL2, or CXCL8, are induced in hypoxic tumor tissue, through the activation of hypoxia-inducible factor 1 (HIF- $1 \alpha$ or $\beta$ ) $[46,57,71]$, and support neutrophil migration to the tumor site via CXCR1 and CXCR2 receptors [72]. Moreover, inflammatory cytokines stimulate G-CSF production in TME and further induce the generation of new neutrophils in bone marrow (cancer-related granulopoiesis) [73,74]. Neutrophils, in turn, contribute to cancer-related inflammation, thus promoting angiogenesis and tumor progression (Figure 1). 


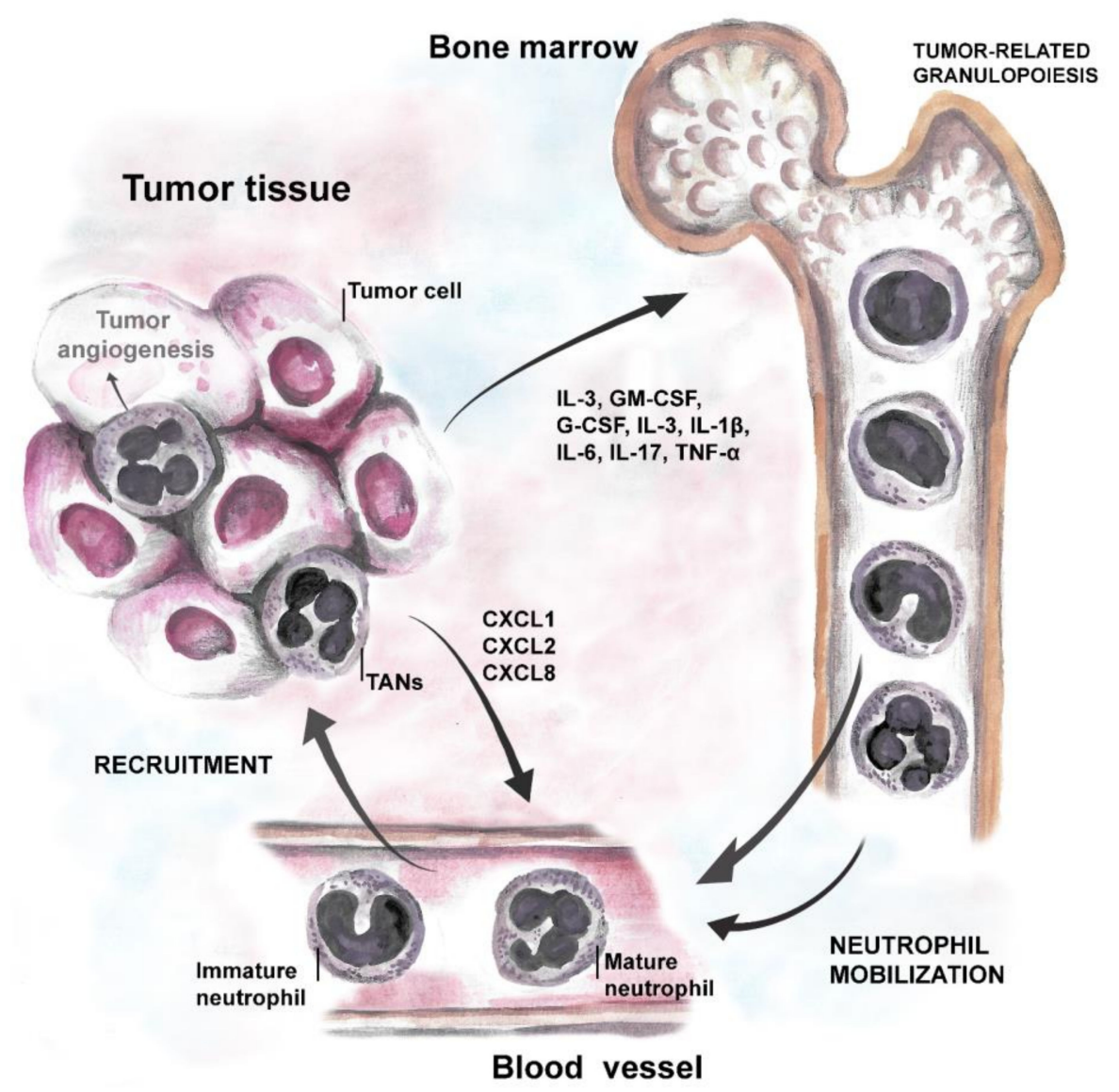

Figure 1. Tumor-neutrophil interactions. Tumor cells produce growth factors (IL-3, GM-CSF, and G-CSF) and inflammatory cytokines (IL-1 $\beta$, IL-6, IL-17, and TNF) that induce neutrophil production and stimulate their survival. Chemoattractants specific for neutrophils, such as CXCL1, CXCL2 (ligands for CXCR2 on neutrophils), and CXCL8 (via CXCR1 on neutrophils) support their migration to the tumor site.

Tumor-associated neutrophils can exert ambivalent functions, ranging from direct killing of tumor cells to promoting tumor angiogenesis, metastasis, and immunosuppression. Similar to tumor-associated macrophages (TAMs), the phenotype and activity of TANs show significant heterogeneity throughout cancer development [75-79]. At the early stage of cancer, neutrophils are mainly located at the periphery of the tumor and display anti-tumoral phenotype, while, at later stages of the disease, their pro-tumoral properties dominate and support further cancer progression [57,80-85]. The pro- or anti-tumoral phenotype of neutrophils in the primary tumor or metastatic site is highly dependent on the cytokine milieu [86]. The functional polarization of TANs, under the influence of TME, and their phenotypic characterization have been previously reviewed in detail elsewhere [46,49,52,56,76,87-89]. It has been shown that IFN signaling triggers the anti-tumor activity of TANs (N1), characterized by normal density and hyper-segmented nucleus $[55,90]$. These cells express high levels of TNF- $\alpha$, CCL3, and ICAM-1; additionally, they show low arginase- 1 expression and are cytotoxic towards cancer cells in the experimental setting [91]. TGF- $\beta$ stimulation or defective type I interferon (IFN) signaling stimulates the pro-tumoral activity of TANs (N2), with low density and both a segmented/not segmented nucleus [75]. These neutrophils can exert immunosuppressive activity, with upregulated expression of CCL2, CCL3, CCL4, CCL8, CCL12, CCL17, CXCL1, CXCL2, IL8/CXCL8, and CXCL16 chemokines [91]. N2 neutrophils promote the genetic instability of cancer cells by producing reactive oxygen species (ROS) and the release of exosomes containing microRNAs that impair nuclear integrity [46]. Moreover, upon G-CSF and TGF- $\beta$ stimulation, neutrophils express arginase-1 (ARG1), ROS, and nitric oxide (NO) 
that contribute to the suppression of T cells $[75,92,93]$. Importantly, it has also been shown that both circulating, and tumor-associated neutrophils could suppress $\mathrm{T}$ cell activation by using immune checkpoint molecules, such as PDL-1 (programmed cell death ligand 1) or VISTA (V-domain immunoglobulin suppressor of T cell activation) [94,95].

\section{Neutrophils and Tumor Angiogenesis}

Neutrophils have been shown to modify their angiogenic capacity under the influence of tumor-derived factors, even before arriving at the TME [96]. Bone marrow neutrophils isolated from naive mice have been reported to suppress tumor growth, while their counterparts from tumor-bearing mice promoted tumor growth [96]. It is generally accepted that the pro-angiogenic properties of tumor-associated neutrophils support cancer progression. The involvement of TANs in tumor angiogenesis was already proposed, in 2006 by Nozawa et al., in a murine pancreatic islet carcinogenesis model. In this study, neutrophils were identified as an important source of MMP-9, and their functional involvement in tumor angiogenesis was demonstrated by the suppression of tumor angiogenic switch after depletion with the anti-Gr-1 antibody [97]. Following this study, the pro-angiogenic activities of neutrophils have been suggested in other cancer types, such as hepatocellular carcinoma, gastric cancer, melanoma, and fibrosarcoma [32,98-100]. In the liver tumorigenesis model, enhanced hypoxia and inflammation in TME have been shown to support the recruitment of neutrophils and promote tumor angiogenesis [98]. Nagaoka et al. demonstrated that IL-17-induced neutrophil infiltration, in a progressive tumor model of gastric cancer, increases tumor angiogenesis and supports tumor persistence [101]. Furthermore, the important role of neutrophil clustering in the vascularization of nasal cavity cancer (nasal inverted papilloma, NIP) was demonstrated recently [102]. MMP-9 and HIF-1 $\alpha$ expressing neutrophils were shown to be the main tumor-infiltrating cells that promoted angiogenesis and significantly contributed to the NIP pathogenesis [102].

In agreement with the essential role of neutrophils in tumor angiogenesis, reduced tumor vascularization and growth have been demonstrated after antibody-mediated neutrophil depletion (using anti-Gr-1 or anti-Ly6G antibody) or inhibition of neutrophil infiltration into tumor tissue (e.g., anti-vascular cell adhesion molecule-1 and anti-VCAM-1) in several studies $[32,97,100]$. Adoptive transfer of anti-angiogenic neutrophils has also been shown to limit tumor angiogenesis in the murine model of melanoma [103-105], while the transfer of pro-angiogenic neutrophils supports tumor vascularization in mice [32,105].

Neutrophils have been recently shown to contribute to tumor vascularization, also through non-angiogenic mechanisms, vessel co-option, and vascular mimicry [106,107]. High neutrophil expression of LOXL4 in colorectal cancer liver metastases (mainly via vessel co-option) has been proposed to be the key factor responsible for the resistance against antiangiogenic therapy [108]. In a very recent study, vascular mimicry (VM) structures (that consisted of cancer-associated fibroblasts (CAFs) and tumor cells) were shown to provide channels for neutrophil infiltration in lung cancer [107]. Such VM structures induced the pro-angiogenic (N2) polarization of infiltrating neutrophils and promoted their arginase, CCL2, CXCR4, and MMP-9 expression and, thus, evade anti-angiogenic therapy [107].

\subsection{Pro-Angiogenic Switch of Neutrophils in Cancer}

Neutrophils support the pro-angiogenic switch during cancer development [97] and are significant producers of pro-angiogenic factors in TME $[109,110]$. Pro-angiogenic factors that are released by neutrophils, such as VEGF, Bv8, MMP-9, and S100A8/S100A9, directly induce tumor angiogenesis via the activation of endothelial cell proliferation $[32,50,97,111]$. Human neutrophils have been shown to carry an intracellular pool of VEGF and mediate its rapid secretion, through the degranulation upon stimulation with phorbol-12-myristate 13-acetate (PMA) and TNF $\alpha$ [112] (Figure 2). 


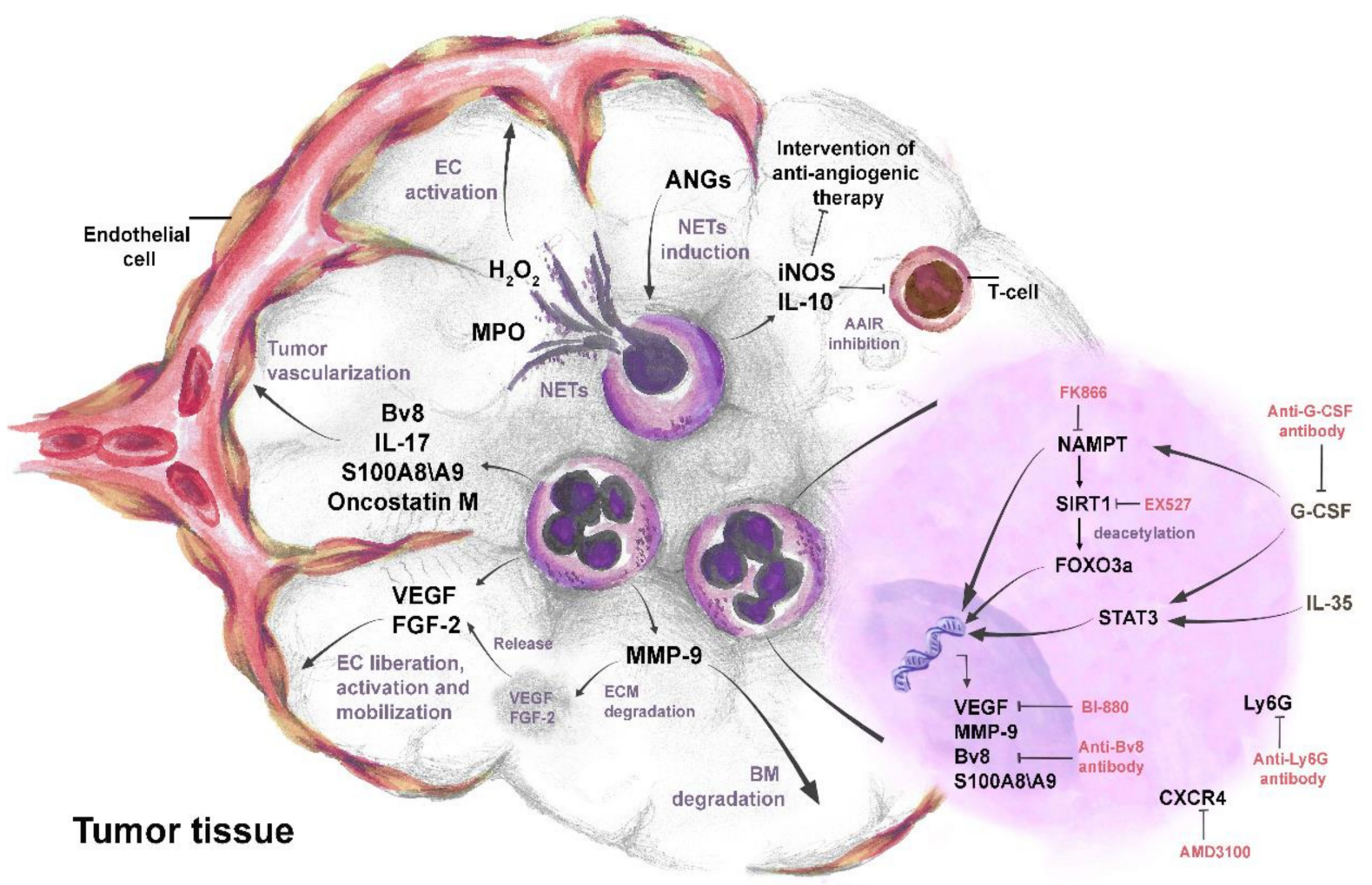

Figure 2. The complex role of neutrophils in tumor angiogenesis. IL-35- and G-CSF-mediated activation of STAT3 and NAMPT pathways leads to the up-regulation and secretion of pro-angiogenic factors VEGF, FGF-2, oncostatin M, IL-17, Bv8, MMP-9, and S100A8/S100A9 in neutrophils. The activated $\mathrm{FOXO} 3$ a transcription factor also contributes to the production of pro-angiogenic factors. Pro-angiogenic factors released from neutrophils directly promote liberation, proliferation, and mobilization of endothelial cells (ECs) and induce tumor angiogenesis. Neutrophil MMP-9 mediates the degradation of the basal membrane (BM) and extracellular matrix (ECM). Degradation of ECM by MMP-9 leads to the release of sequestered VEGF and FGF-2 in ECM. Angiopoietins (ANGs) induce neutrophil extracellular trap (NET) formation in neutrophils. MPO in NETs increases $\mathrm{H}_{2} \mathrm{O}_{2}$ and stimulates proliferation and mobility of ECs. Neutrophils secrete IL-10 and iNOS to suppress antiangiogenic adaptive immune response (AAIR) and later sustain tumor escape from anti-angiogenic therapy. Anti-Ly6G, anti-G-CSF, and anti-Bv8 antibodies inhibit neutrophil mediated tumor angiogenesis. Targeting NAMPT, SIRT1, VEGF, and CXCR4 in neutrophils, using molecular inhibitors such as FK866, EX527, BI-880, and AMD3100, respectively, reduces their pro-angiogenic activity.

In addition to their direct pro-angiogenic function, neutrophils can also activate proangiogenic functions of other immune cells and, thus, indirectly contribute to angiogenesis. It was previously demonstrated that human neutrophils can induce regulatory-like phenotypes of T cells and support their expression of IL-10, IL-17, and VEGF to promote vessel growth in pregnancy [113]. Possibly similar mechanisms could take place in the tumor microenvironment. Neutrophils could also affect anti-tumoral adaptive immune responses to support tumor angiogenesis [114]. In one study, Zou et al. identified pro-angiogenic immunosuppressive N2 neutrophils by producing iNOS inhibited T cell activation and suppressed anti-tumor adaptive immune responses, thus promoting tumor cell survival and proliferation [114].

Cancer metastasis constitute a major challenge in effective cancer therapy. Proangiogenic neutrophils have also been shown as significant supporters of tumor cell detachment and cancer metastasis $[115,116]$. In an animal model of breast cancer, JUNB deficiency was shown to increase neutrophil infiltration in the metastatic lung. Such neutrophils released elevated amounts of MMP-9 and BV8, leading to enhanced lung metastasis [117]. 
Importantly, neutrophils can also interfere with anti-angiogenic therapies. It was shown that the infiltration of $\mathrm{CD}_{11} \mathrm{~b}^{+} \mathrm{Gr} 1^{+}$myeloid cells (neutrophils) into tumor significantly reduced the efficacy of anti-VEGF antibody therapy [118]. Moreover, by secreting immunosuppressive cytokine IL-10 and hampering of T cell proliferation, neutrophils were shown to sustain tumor escape from anti-angiogenic therapy [119].

\subsection{Neutrophil-Derived Factors That Support Tumor Angiogenesis}

Neutrophils have been shown to support tumor angiogenesis via the release of numerous pro-angiogenic factors, such as VEGF, FGF-2, oncostatin M, IL-17, MMP-9, Bv8, S100A8/9 alarmins, STAT3, and NETs. Identification of other possible pro-angiogenic factors could support further approaches in successful cancer therapy.

\subsubsection{VEGF and FGF-2}

VEGF is a major pro-angiogenic factor, and VEGF signaling plays a central role in both physiological and pathological angiogenesis. It has been shown that human neutrophils carry an intracellular pool of VEGF and release it during the process of degranulation, upon stimulation with PMA, fMet-Leu-Phe (fMLP), and TNF- $\alpha$ [112]. Interestingly, neutrophils were found to be the main source of the circulating VEGF in the majority of patients with metastatic breast cancer or anal carcinoma [120]. Another study has reported that circulating neutrophils release higher amounts of VEGF in patients with oral cavity cancer, compared to healthy donor counterparts [121]. Furthermore, it has been shown that neutrophil depletion is linked to the inhibition of angiogenesis because of the reduced release of pre-formed neutrophil VEGF stores [122]. Importantly, elevated infiltration of tumor tissue by $\mathrm{CD} 11 \mathrm{~b}^{+} \mathrm{Gr}^{+}$neutrophils, characterized by the increased expression of VEGF, was demonstrated to contribute to tumor angiogenesis in a mouse model of fibrosarcoma and melanoma [32].

Surprisingly, VEGF was also shown to indirectly affect neutrophil recruitment. It was reported that IL-8 expression by endothelial cells after VEGF stimulation induced neutrophil migration in vitro [123]. Moreover, VEGF production by neutrophils might promote the further recruitment of neutrophils, in a positive feedback loop, to establish pro-angiogenic signaling inside the tumor and support tumor angiogenesis.

Additionally, neutrophils have been shown to produce and/or contribute to the release of FGF-2. The direct FGF-2 expression of tumor-infiltrating neutrophils was demonstrated in the mouse model of hepatic metastases from gastrointestinal tumors [116]. In this study, neutrophils from hepatic metastases were shown to abundantly express FGF-2 mRNA and promote angiogenesis. Furthermore, neutrophil activity stimulates the release and bioavailability of sequestered FGF-2 in the extracellular matrix [124,125].

\subsubsection{Oncostatin M and IL-17}

Oncostatin $\mathrm{M}$ is a cytokine produced by $\mathrm{T}$ cells, monocytes, and neutrophils. In early studies, oncostatin $\mathrm{M}$ has been shown to inhibit cancer cell proliferation and tumor growth $[126,127]$. However, neutrophil-secreted oncostatin $M$ has been suggested to contribute to angiogenesis and invasiveness of breast cancer [115]. When co-cultured with breast cancer cells in vitro, human blood neutrophils have been shown to express oncostatin M [115]. Furthermore, both the cell-cell contact and GM-CSF production of breast cancer cells were demonstrated to be necessary for the oncostatin $M$ release from neutrophils. Importantly, GM-CSF-dependent production of oncostatin M by neutrophils has been shown to promote the invasiveness and VEGF expression of MDA-MB-231 and T47D human breast cancer cells [115].

Neutrophil-derived IL-17 has also been suggested to induce tumor angiogenesis [128]. Numasaki et al. demonstrated that IL-17 enhances the angiogenic activity and in vivo growth of non-small cell lung cancer (NSCLC) by promoting the expression of angiogenic chemokines (CXCL1, CXCL5, CXCL6, and CXCL8) [128]. Interestingly, tumor infiltrating T cells and neutrophils were identified as the major source of IL-17 in NSCLC tissue [128]. 


\subsubsection{MMP-9}

MMPs are reported to be highly expressed in various cancer types and are commonly associated with the tumor progression [129-131]. MMP-9 is a gelatinase that mediates the remodeling of the extracellular membrane, and it has been demonstrated to play an important role in tumor angiogenesis by triggering the angiogenic switch [132]. Importantly, tumor-associated neutrophils were reported to have significantly more abundant MMP-9, readily available for rapid release, than tumor-associated macrophages [133]. Neutrophil-produced MMP-9 mediates degradation of the basal membrane and leads to the liberation and activation of ECs. The degradation of the basal membrane, by MMP-9, indirectly leads to the release of pro-angiogenic factors VEGF and FGF-2, stored in extracellular matrix $[97,116,125,134]$. VEGF, sequestered in the tumor extracellular matrix, after being released by MMP-9, increases further neutrophilic expression of MMP-9 in a positive feedback fashion [135]. VEGF-A was also demonstrated as a chemoattractant for MMP-9expressing neutrophils [136]. Moreover, increased levels of VEGF-A in hypoxic regions recruit a distinct subpopulation of pro-angiogenic neutrophils that are characterized by the expression profile of CD49d ${ }^{+}$VEGFR ${ }^{\text {hi }}$ CXCR $4{ }^{\text {hi }}$ [137]. Neutrophil MMP-9 also increases VEGF-A bioavailability and bioactivity and contributes to the inflammation-induced lymphangiogenesis [138]. Li et al. recently identified high levels of IL- $17^{+}$neutrophils as the major source of MMP-9 in the invasive margin of gastric cancer [139]. In this study, IL-17 producing neutrophils were shown to promote the pro-angiogenic activity of cancer cells, both in vivo and in vitro. Moreover, such neutrophils stimulated cancer cells to produce neutrophil chemoattractants, which, in turn, supported further neutrophil recruitment [139]. The pro-angiogenic role of MMP-9-secreting neutrophils in tumor vascularization was also validated in other types of cancer. In primary tumors formed by highly disseminating variants of human fibrosarcoma and prostate carcinoma, an elevated accumulation of MMP-9-positive neutrophils was demonstrated. The inhibition of neutrophil recruitment into such tumors, by IL-8 neutralization, diminished tumor angiogenesis [140].

\subsubsection{Bv8 and S100A8/9 Alarmins}

Neutrophil-derived Bv8 and S100 proteins (S100A8 and S100A9) increase tumor proliferation and angiogenesis by supporting neutrophil mobilization, EC activation, and proliferation [46,141-143]. Tumor-associated neutrophils have been shown to produce Bv8 and S100A8 in a mouse melanoma model [105]. Bv8 has been suggested as a modulator of myeloid-cell-dependent tumor angiogenesis, and neutrophils have been reported to produce Bv8 robustly, after stimulation with G-CSF or GM-CSF [142,144]. Recently, Itatani et al. demonstrated that tumor-infiltrating neutrophils strongly expressed Bv8 in a mouse model of colorectal cancer. Importantly, in the same study, significantly higher plasma levels of Bv8 were observed in CRC patients, compared to healthy donors. Moreover, high plasma levels of Bv8 positively correlated with a bad prognosis and decreased overall survival of such patients [145]. In another study, treatment with anti-Bv8 antibodies reduced the number of angiogenic islets in transgenic mouse model of multistage pancreatic $\beta$-cell tumorigenesis [111]. Moreover, such anti-Bv8 treatment inhibited the recruitment of $\mathrm{CD} 11 \mathrm{~b}^{+} \mathrm{Gr}^{+}$neutrophils to the neoplastic lesions [111,118,146]. Apart from direct stimulation of tumor angiogenesis, neutrophil-derived Bv8 also plays a role in tumor resistance to anti-VEGF therapy (see chapter 7) [145]. Increased levels of plasma G-CSF, after anti-VEGF therapy of mice bearing VEGF-resistant colorectal tumors, were shown to promote neutrophil infiltration into tumor stroma and stimulate angiogenesis via elevated neutrophil Bv8 expression [145]. This study demonstrates that blocking neutrophil-derived Bv8 increases the efficacy of anti-VEGF antibody therapy in colorectal cancer [145].

\subsubsection{STAT3}

STAT3 is transcription factor that is involved in cell proliferation, survival, and angiogenesis [147]. STAT3 has been reported to be constitutively activated in both tumor and immune cells in the tumor microenvironment [147-149]. Neutrophil STAT3 activity 
(triggered via G-CSF/G-CSFR pathway) is important for their production, survival, and mobilization from the bone marrow [150-152]. STAT3 signaling in mice has been shown to have a regulatory role in neutrophil pro-angiogenic activity by controlling the expression of VEGFA, FGF-2, and MMP-9 genes [153]. Importantly, it has also been demonstrated that neutrophils isolated from tumors have activated STAT3 and induce angiogenesis in vitro [153]. STAT3 signaling in neutrophils was suggested to activate neutrophil proangiogenic functions, even before they entered the TME [96]. Stimulation by G-CSF and IL-6 was shown to increase Stat3 expression, which then led to the upregulation of MMP-9 and $B v 8$ genes in bone marrow neutrophils [96]. Mechanistically, G-CSF-mediated STAT3 activation induces binding of phospho-STAT3 to the Bv8 promotor and elevates the expression of Bv8 [154]. The inhibition of Stat3, by type I IFN signaling, impairs VEGF and MMP-9 production by neutrophils and suppresses tumor angiogenesis [32].

\subsection{The Role of Neutrophil Extracellular Traps in Angiogenesis}

Neutrophils contribute to inflammatory angiogenesis, also by neutrophil extracellular trap (NET) formation. Myeloperoxidase that is attached to such NETs increase $\mathrm{H}_{2} \mathrm{O}_{2}$ in ECM and leads to the activation of NFkB-mediated inflammatory signaling in ECs via TLR4. This initiates proliferation and mobility of endothelial cells and, as a result, tumor angiogenesis [155]. It has previously been shown that cancer cells are able to induce NET formation by neutrophils and, thus, to promote tumor angiogenesis [156]. Angiopoietins (ANG-1 and ANG-2) also were shown to induce NETs formation and contribute to proinflammatory and pro-angiogenic activities of neutrophils [157]. Angiopoietin-induced NETosis of human neutrophils promoted neutrophil adhesion to HUVECs and stimulated their proliferation [157].

\section{Mechanisms Regulating Pro- and Anti-Angiogenic Activity of Neutrophils in Cancer}

Neutrophil angiogenic activity can be modulated by multiple tumor-released factors. Many signaling pathways have been suggested to promote neutrophil pro-angiogenic functions. Type I interferon signaling is one of the most prominent pathways that has been shown to strongly influence angiogenic potential of neutrophils. Owing to their ability to promote anti-tumoral (N1) neutrophil differentiation, IFNs inhibit neutrophil expression of pro-angiogenic factors. It has been demonstrated that in vivo transfection of IFN- $\beta$-expressing vector downregulated $M M P-9$ and $B v 8$ expression in neutrophils isolated from the bone marrow of tumor-bearing mice. This process was shown to be STAT3dependent [96]. Another study showed that the deficiency of type I IFN supports proangiogenic switch of tumor-associated neutrophils and enhances tumor angiogenesis and growth [32]. Tumors from IFN- $\beta^{-/-}$mice show increased infiltration with pro-angiogenic neutrophils, characterized by the elevated levels of STAT3, MMP-9, and VEGF [32]. Transfer of such pro-angiogenic neutrophils into WT mice significantly elevated tumor growth. Importantly, the treatment of IFN- $\beta^{-/-}$neutrophils with rmIFN- $\beta$ reduced their proangiogenic activity [32]. Similarly, IFN receptor-deficient mice (Ifnar ${ }^{-/}$) showed elevated tumor angiogenesis and neutrophil infiltration in the tumor tissue [105]. Neutrophils from such mice significantly up-regulated their expression of $V E G F, M M P-9, B v 8$, and S100A8 [105].

It has been demonstrated that the pro-angiogenic properties of neutrophils are stimulated by the activation of nicotinamide phosphoribosyl transferase (NAMPT) signaling pathway, downstream of G-CSF receptor [104]. It was shown that NAMPT expression in pro-angiogenic neutrophils is significantly upregulated and that the inhibition of NAMPT by the small molecule inhibitor FK866 impaired the pro-angiogenic phenotype of such tumor-associated neutrophils. Transfer of such neutrophils into tumor-bearing mice reduced tumor angiogenesis and growth [103,104].

Recently, another mechanism was shown to regulate the angiogenic potential of tumorassociated neutrophils. Bordbari et al. demonstrated that the pro-angiogenic capacity of neutrophils is strictly regulated by the post-translational modification of FOXO3a tran- 
scription factor that controls transcription of pro-angiogenic genes [105]. SIRT1-mediated deacetylation of FOXO3a was shown to activate this factor, while the phosphorylation, in the absence of SIRT1, led to cytoplasmic transfer and deactivation of FOXO3a [105]. Activated FOXO3a has been demonstrated to induce the transcription of pro-angiogenic molecules like VEGF, MMP-9, BV8, and S100A8 in TANs [105].

The CXCR2 receptor, on neutrophils, is the main regulator of neutrophil chemotaxis and function. Elevated expression of CXCR2 ligands (CXCL1, 2, 3, 5, 6, 7, and 8) is observed in various tumor types, such as lung cancer [158-160], hepatocellular carcinoma [161], renal cell carcinoma [162], and melanoma [72]. These chemokines can be directly secreted by cancer cells, endothelial cells, and cancer-associated fibroblasts, as well as by immune cells, including neutrophils [72]. High expression of CXCR2 ligands has been correlated with tumor aggressiveness in several types of tumors [163]. Moreover, CXCR2 depletion has been shown to have a negative effect on tumor growth and angiogenesis in a mouse model of lung cancer [164] and melanoma [72]. However, Timaxian et al. showed that the loss of CXCR2 in a murine breast cancer model resulted in increased growth of the primary tumor and lung metastasis. In that study, increased infiltration of tumors by pro-angiogenic TANs was observed [165]. Possibly, other neutrophil-attracting chemokines (such as CXCR4) compensated for the loss of CXCR2 in this experimental setting and attracted pro-angiogenic neutrophils into the tumor tissue. Nonetheless, this phenomenon must be further investigated.

One such chemokine could be CXCL12 (a ligand for CXCR4), which was described to be overexpressed in melanoma [32] and other tumors [166]. It has been previously shown that CXCL12, in co-operation with IL-8, promotes angiogenesis in pancreatic cancer; therefore, CXCR4 could be a potential anti-angiogenic therapeutic target [167]. In a recent study, Tulotta et al. demonstrated the role of CXCR4/CXCL12 signaling in neutrophiltumor cell interactions [168]. Importantly, pro-angiogenic neutrophils have been shown to express high CXCR4 in different studies [32,137].

Recently, IL-35 was shown to promote neutrophil infiltration and pro-angiogenic activity of neutrophils in TME. By inducing the polarization of neutrophils towards pro-angiogenic N2 phenotype, IL-35 supports the release of MMP-9 and Bv8 from neutrophils [114]. Additionally, in the same study, IL-35 has also been demonstrated to induce the activation of STAT3 and ERK pathway in neutrophils to upregulate their iNOS production, in order to suppress anti-angiogenic function of T cells [114].

Not only can cytokines or growth factors can modulate angiogenic activity of neutrophils. One isoform of plasma membrane vacuolar ATPase (a2V) was found to be secreted in several cancer types and suggested as a factor that mediates neutrophil recruitment to tumors [169]. Neutrophils treated with cancer-associated a2V showed prolonged survival [170] and elevated pro-angiogenic activity, with elevated expression of MMP-9 and VEGF [171].

Besides tumor cells, cancer-associated fibroblasts (CAFs) can also induce neutrophil pro-angiogenic activity and support tumor angiogenesis. CAFs in the lung cancer have been shown to express high levels of neutrophil chemoattractants, such as IL-6, IL-8, and CXCL1, and further support neutrophil recruitment by increasing their surface expression of VCAM and ICAM2 [107]. These CAFs significantly promote the infiltration of arginase+ N2 neutrophils and stimulate their expression of CXCL2, CXCR4, and MMP9 [107]. Furthermore, it has been shown that CAFs mediate the activation of TGF- $\beta / \operatorname{Smad} 3$ signaling in tumor cells to induce IL-8 secretion and promote $\mathrm{MPO}^{+}$neutrophil migration in lung cancer [172]. These $\mathrm{MPO}^{+}$neutrophils have been reported to contribute to the tumor progression, through the support of angiogenesis. Additionally, by releasing MMP-9, these neutrophils were suggested to promote further activation of TGF $\beta$ in tumor microenvironment [172].

The effect of natural killer cells (NK cells) on angiogenic properties of neutrophils has been indicated [173]. By producing IFN $\gamma$ and GM-CSF, NK cells have been shown to activate neutrophils and induce their surface expression of CD11b, CD62L, and CD64 [173]. 
After the activation by NK-derived factors, such neutrophils supported tumor angiogenesis by releasing VEGF and MMP-9. Moreover, they upregulated ARG1 expression, resulting in tumor growth [173], possibly by suppressing anti-tumoral T cell functions. On the other hand, Ogura et al. demonstrated that NK-derived IFN $\gamma$ is able to inhibit VEGF expression of neutrophil [174], once again showing the complexity of the cell-cell interactions in tumor angiogenesis.

\section{The Role of Neutrophils during Anti-Angiogenic Therapy and Possible Therapeutic Approaches}

The very first studies on anti-angiogenic therapies have focused on blocking VEGF/ VEGFR signaling with specific monoclonal antibodies [175]. Bevacizumab (VEGF-A mAb) or ramucirumab (VEGFR2 $\mathrm{mAb}$ ) are the foremost Food and Drug Administration (FDA) approved drugs in the treatment of angiogenesis in cancer. However, these drugs reached a very limited success in the clinical trials, due to the tumor resistance [175], and it has been suggested that neutrophils play a significant role in this phenomenon [176]. Therefore, a growing body of evidence suggests therapeutic approaches, aiming at the inhibition of neutrophil pro-angiogenic role (summarized in Table 1).

Table 1. Complementary neutrophil-targeting, anti-angiogenic therapy approaches.

\begin{tabular}{cccc}
\hline Therapy & Compound & Target & Reference \\
\hline Anti-Ly6G & Monoclonal antibody & Neutrophil recruitment & {$[119]$} \\
AMD3100 & CXCR4 inhibitor & Neutrophil recruitment & {$[177]$} \\
BI-880 & bi-specific VEGF/Ang2 & Neutrophil recruitment & {$[176]$} \\
& blocking nanobody & Neutrophil & {$[145]$} \\
Anti-G-CSF & Monoclonal antibody & recruitment/production & {$[145]$} \\
Anti-Bv8/PROK2 & Monoclonal antibody & Neutrophil Bv8 & {$[103]$} \\
FK866 & Molecular inhibitor & Neutrophil NAMPT & {$[105]$} \\
\hline
\end{tabular}

The effect of neutrophils on the resistance to anti-VEGF therapy was demonstrated by Jung et al., who showed that the increased neutrophil infiltration after anti-VEGFR2 administration promotes tumor angiogenesis and decreases the efficacy of the therapy [119]. In that study, it has been shown that Ly6 $6 C^{\text {lo }}$ monocytes present in TME facilitate the recruitment of Ly6G+ neutrophils after anti-VEGFR2 therapy via the release of CXCL5. Interestingly, combining a neutrophil-targeting treatment with an anti-angiogenic therapy by the administration of anti-Ly6G antibody has been shown to reverse this effect, limit angiogenesis, and to support anti-VEGFR2 therapy [119]. The same research group demonstrated in another study that the anti-angiogenic treatment increases the expression of CXCL12 in tumors and leads to the recruitment of $\mathrm{CXCR}^{+}$pro-angiogenic neutrophils [177]. The blockade of CXCR4, by an FDA-approved agent AMD3100, inhibited Ly6G ${ }^{+}$neutrophil infiltration into the tumor and improved the efficacy of anti-VEGF therapy [177].

Enhanced tumor inflammation, upon anti-VEGF therapy, was suggested as another reason for neutrophil infiltration into metastatic tumors of colorectal cancer (CRC) patients. The presence of $\mathrm{CD} 177^{+}$tumor-infiltrating neutrophils was demonstrated by immunostainings of TMAs, derived from colorectal metastasis samples [176]. The combination of traditional anti-angiogenic therapy (bevacizumab) and novel bi-specific VEGF/ Ang2 blocking nanobody BI-880 diminished neutrophil infiltration and efficiently reduced angiogenesis, tumor growth, and hypoxia [176].

It has been shown that mice bearing VEGF-resistant colorectal tumors have elevated levels of plasma G-CSF, which leads to strong mobilization of neutrophils, their tumor infiltration, and induction of Bv8 expression that supports tumor angiogenesis [145]. Anti-VEGF therapy, in combination with anti-G-CSF or anti-Bv8/PROK2 antibodies, was demonstrated to efficiently suppress tumor growth [145]. 
Recently, a novel tool to manipulate pro-angiogenic capacity of TANs was suggested. The molecular inhibitor of NAMPT (FK866) was shown to repolarize neutrophils into an anti-angiogenic state $[103,104]$. Transfer of such anti-angiogenic TANs into tumor-bearing mice significantly impaired tumor growth. Moreover, histological examinations proved the significant suppression of angiogenesis in such tumors [103]. Furthermore, targeting neutrophil deacetylase SIRT1, which is a downstream target of NAMPT and, at the same time, an activator of pro-angiogenic transcription factor FOXO3a, was shown to suppress the pro-angiogenic activity of TANs [105].

\section{Future Perspectives}

Neutrophils contribute to tumor angiogenesis by direct secretion of pro-angiogenic molecules and the stimulation of endothelial cell proliferation. Furthermore, neutrophil recruitment and pro-angiogenic activity constitute a handicap in effective anti-angiogenic therapy. Standard anti-VEGF treatment showed, so far, moderate efficacy due to tumor resistance. Moreover, the growing body of evidence suggests that anti-VEGF therapy attracts neutrophils, induces their pro-angiogenic properties and leads to tumor therapy resistance. Therefore, going beyond the ordinary and designing therapeutic approaches simultaneously targeting neutrophils and tumor angiogenesis are necessary to provide a successful cancer treatment. In fact, combining anti-angiogenic therapy and immunotherapy has already been demonstrated as a beneficial strategy in cancer treatment $[178,179]$. Inhibition of neutrophil infiltration into tumors hold great promise to be the complementary to the traditional anti-angiogenic cancer therapy. G-CSF, GM-CSF, CXCR2, and CXCR4 are the most promising targets to control neutrophil migration. A growing body of evidence has been validated that inhibiting or manipulating neutrophil pro-angiogenic pathways, using molecular inhibitors or antibodies, in combination with anti-VEGF therapy, improves the outcome of anti-angiogenic therapy. In order to provide efficient delivery of anti-angiogenic molecules to neutrophils, another way of delivery should be re-considered. One such possibility could be nanoparticles, as these structures has been already demonstrated in various studies to effectively deliver their cargo, such as siRNA or proteins, into target cells [180]. Human and mouse neutrophils were shown to be successfully transfected with siRNA by using CD177-mediated nanoparticles [181]. Such technology could be optimized for the delivery of siRNA or proteins targeting the neutrophil release of pro-angiogenic factors in TME.

\section{Conclusions}

Neutrophils are one of the major players in regulating cancer growth from the early stages. Neutrophil-mediated tumor angiogenesis and metastasis handicap achieving a success in the treatment of many types of cancer. Nevertheless, targeting both angiogenesis and neutrophil functions in cancer shows a lot of potential and could take cancer immunotherapy a step further.

Author Contributions: Manuscript conceptualization, design, writing: I.O., I.D., E.P., M.D., and J.J.; manuscript editing: I.O., I.D., E.P., M.D., S.L., and J.J.; visualization, I.D., E.P., and M.D.; supervision, J.J. All authors have read and agreed to the published version of the manuscript.

Funding: This work was supported by Deutsche Forschungsgemeinschaft (DFG/JA 2461/5-1 and DFG/JA 2461/7-1) and Deutsche Krebshilfe (111647). E.P. was supported by the IFORES PEP-BIOME excellence program of University of Duisburg-Essen.

Acknowledgments: We acknowledge support by the Open Access Publication Fund of the University of Duisburg-Essen.

Conflicts of Interest: The authors declare no conflict of interest. The funders had no role in the design and the writing of the manuscript. 


\section{References}

1. Potente, M.; Gerhardt, H.; Carmeliet, P. Basic and Therapeutic Aspects of Angiogenesis. Cell 2011, 146, 873-887. [CrossRef]

2. Saman, H.; Raza, S.S.; Uddin, S.; Rasul, K. Inducing Angiogenesis, a Key Step in Cancer Vascularization, and Treatment Approaches. Cancers 2020, 12, 1172. [CrossRef]

3. Carmeliet, P. Angiogenesis in health and disease. Nat. Med. 2003, 9, 653-660. [CrossRef] [PubMed]

4. Sherwood, L.M.; Parris, E.E.; Folkman, J. Tumor Angiogenesis: Therapeutic Implications. N. Engl. J. Med. 1971, $285,1182-1186$. [CrossRef] [PubMed]

5. Bielenberg, D.R.; Zetter, B.R. The Contribution of Angiogenesis to the Process of Metastasis. Cancer J. 2015, 21, 267-273. [CrossRef] [PubMed]

6. Kazerounian, S.; Lawler, J. Integration of pro- and anti-angiogenic signals by endothelial cells. J. Cell Commun. Signal. 2018, 12, 171-179. [CrossRef]

7. Jeong, J.-H.; Ojha, U.; Lee, Y.M. Pathological angiogenesis and inflammation in tissues. Arch. Pharm. Res. 2021, 44, 1-15. [CrossRef] [PubMed]

8. De Spiegelaere, W.; Casteleyn, C.; Van den Broeck, W.; Plendl, J.; Bahramsoltani, M.; Simoens, P.; Djonov, V.; Cornillie, P. Intussusceptive Angiogenesis: A Biologically Relevant Form of Angiogenesis. J. Vasc. Res. 2012, 49, 390-404. [CrossRef]

9. Djonov, V.; Baum, O.; Burri, P.H. Vascular remodeling by intussusceptive angiogenesis. Cell Tissue Res. 2003, 314, 107-117. [CrossRef]

10. Lugano, R.; Ramachandran, M.; Dimberg, A. Tumor angiogenesis: Causes, consequences, challenges and opportunities. Cell. Mol Life Sci. 2020, 77, 1745-1770. [CrossRef]

11. Sainson, R.C.A.; Johnston, D.A.; Chu, H.C.; Holderfield, M.T.; Nakatsu, M.N.; Crampton, S.P.; Davis, J.; Conn, E.; Hughes, C.C.W. TNF primes endothelial cells for angiogenic sprouting by inducing a tip cell phenotype. Blood 2008, 111, 4997-5007. [CrossRef]

12. Marech, I.; Leporini, C.; Ammendola, M.; Porcelli, M.; Gadaleta, C.D.; Russo, E.; De Sarro, G.; Ranieri, G. Classical and nonclassical proangiogenic factors as a target of antiangiogenic therapy in tumor microenvironment. Cancer Lett. 2016, 380, 216-226. [CrossRef]

13. Eelen, G.; Treps, L.; Li, X.; Carmeliet, P. Basic and Therapeutic Aspects of Angiogenesis Updated. Circ. Res. 2020, 127, 310-329. [CrossRef]

14. Elsherbiny, A.; Högger, D.C.; Borozadi, M.K.; Schmidt, C.A.; Plock, J.; Largo, R.D.; Lindenblatt, N.; Giovanoli, P.; Contaldo, C EPO reverses defective wound repair in hypercholesterolaemic mice by increasing functional angiogenesis. J. Plast. Reconstr. Aesthetic Surg. 2012, 65, 1559-1568. [CrossRef]

15. Helker, C.S.M.; Eberlein, J.; Wilhelm, K.; Sugino, T.; Malchow, J.; Schuermann, A.; Baumeister, S.; Kwon, H.B.; Maischein, H.M.; Potente, M.; et al. Apelin signaling drives vascular endothelial cells towards a pro-angiogenic state. Elife 2020, 9, e55589. [CrossRef] [PubMed]

16. Dardik, R.; Loscalzo, J.; Eskaraev, R.; Inbal, A. Molecular mechanisms underlying the proangiogenic effect of factor XIII. Arterioscler Thromb. Vasc. Biol. 2005, 25, 526-532. [CrossRef] [PubMed]

17. Carmi, Y.; Voronov, E.; Dotan, S.; Lahat, N.; Rahat, M.A.; Fogel, M.; Huszar, M.; White, M.R.; Dinarello, C.A.; Apte, R.N. The Role of Macrophage-Derived IL-1 in Induction and Maintenance of Angiogenesis. J. Immunol. 2009, 183, 4705-4714. [CrossRef] [PubMed]

18. Holen, I.; Lefley, D.V.; Francis, S.E.; Rennicks, S.; Bradbury, S.; Coleman, R.E.; Ottewell, P. IL-1 drives breast cancer growth and bone metastasis in vivo. Oncotarget 2016, 7, 75571-75584. [CrossRef] [PubMed]

19. Amin, M.A.; Rabquer, B.J.; Mansfield, P.J.; Ruth, J.H.; Marotte, H.; Haas, C.S.; Reamer, E.N.; Koch, A.E. Interleukin 18 induces angiogenesis in vitro and in vivo via Src and Jnk kinases. Ann. Rheum. Dis. 2010, 69, 2204-2212. [CrossRef]

20. Kobori, T.; Hamasaki, S.; Kitaura, A.; Yamazaki, Y.; Nishinaka, T.; Niwa, A.; Nakao, S.; Wake, H.; Mori, S.; Yoshino, T.; et al Interleukin-18 amplifies macrophage polarization and morphological alteration, leading to excessive angiogenesis. Front. Immunol. 2018, 9, 334. [CrossRef] [PubMed]

21. Ma, J.; Sun, X.; Guo, T.; Su, H.; Chen, Q.; Gong, Z.; Qi, J.; Zhao, X. Interleukin-1 receptor antagonist inhibits angiogenesis via blockage IL-1 $\alpha /$ PI3K/NF-kB pathway in human colon cancer cell. Cancer Manag. Res. 2017, 9, 481-493. [CrossRef] [PubMed]

22. Gong, Z.; Ma, J.; Su, H.; Guo, T.; Cai, H.; Chen, Q.; Zhao, X.; Qi, J.; Du, J. Interleukin-1 receptor antagonist inhibits angiogenesis in gastric cancer. Int. J. Clin. Oncol. 2018, 23, 659-670. [CrossRef] [PubMed]

23. Kang, T.-Y.; Bocci, F.; Jolly, M.K.; Levine, H.; Onuchic, J.N.; Levchenko, A. Pericytes enable effective angiogenesis in the presence of proinflammatory signals. Proc. Natl. Acad. Sci. USA 2019, 116, 23551-23561. [CrossRef] [PubMed]

24. Gao, W.; Liang, T.; He, R.; Ren, J.; Yao, H.; Wang, K.; Zhu, L.; Xu, Y. Exosomes from 3D culture of marrow stem cells enhances endothelial cell proliferation, migration, and angiogenesis via activation of the HMGB1/AKT pathway. Stem Cell Res. 2021, 50, 102122. [CrossRef] [PubMed]

25. Rosenberger, L.; Ezquer, M.; Lillo-Vera, F.; Pedraza, P.L.; Ortúzar, M.I.; González, P.L.; Figueroa-Valdés, A.I.; Cuenca, J.; Ezquer, F.; Khoury, M.; et al. Stem cell exosomes inhibit angiogenesis and tumor growth of oral squamous cell carcinoma. Sci. Rep. 2019, 9, 663. [CrossRef]

26. Mao, Y.; Wang, Y.; Dong, L.; Zhang, Y.; Zhang, Y.; Wang, C.; Zhang, Q.; Yang, S.; Cao, L.; Zhang, X.; et al. Hypoxic exosomes facilitate angiogenesis and metastasis in esophageal squamous cell carcinoma through altering the phenotype and transcriptome of endothelial cells. J. Exp. Clin. Cancer Res. 2019, 38, 389. [CrossRef] 
27. Gao, L.; Mei, S.; Zhang, S.; Qin, Q.; Li, H.; Liao, Y.; Fan, H.; Liu, Z.; Zhu, H. Cardio-renal exosomes in myocardial infarction serum regulate proangiogenic paracrine signaling in adipose mesenchymal stem cells. Theranostics 2020, 10, 1060-1073. [CrossRef]

28. Ju, Y.; Tang, Z.; Dai, X.; Gao, H.; Zhang, J.; Liu, Y.; Yang, Y.; Ni, N.; Zhang, D.; Wang, Y.; et al. Protection against light-induced retinal degeneration via dual anti-inflammatory and anti-angiogenic functions of thrombospondin-1. Br. J. Pharmacol. 2020; in press. [CrossRef]

29. Wang, S.; Lu, X.; Liu, P.; Fu, Y.; Jia, L.; Zhan, S.; Luo, Y. Endostatin Has ATPase Activity, Which Mediates Its Antiangiogenic and Antitumor Activities. Mol. Cancer Ther. 2015, 14, 1192-1201. [CrossRef]

30. Harkness, L.M.; Weckmann, M.; Kopp, M.; Becker, T.; Ashton, A.W.; Burgess, J.K. Tumstatin regulates the angiogenic and inflammatory potential of airway smooth muscle extracellular matrix. J. Cell. Mol. Med. 2017, 21, 3288-3297. [CrossRef]

31. von Marschall, Z.; Scholz, A.; Cramer, T.; Schafer, G.; Schirner, M.; Oberg, K.; Wiedenmann, B.; Hocker, M.; Rosewicz, S. Effects of Interferon Alpha on Vascular Endothelial Growth Factor Gene Transcription and Tumor Angiogenesis. J. Natl. Cancer Inst. 2003, 95, 437-448. [CrossRef] [PubMed]

32. Jablonska, J.; Leschner, S.; Westphal, K.; Lienenklaus, S.; Weiss, S. Neutrophils responsive to endogenous IFN- $\beta$ regulate tumor angiogenesis and growth in a mouse tumor model. J. Clin. Investig. 2010, 120, 1151-1164. [CrossRef] [PubMed]

33. Balamurugan, K. HIF-1 at the crossroads of hypoxia, inflammation, and cancer. Int. J. Cancer 2016, 138, 1058-1066. [CrossRef] [PubMed]

34. Yang, Y.; Sun, M.; Wang, L.; Jiao, B. HIFs, angiogenesis, and cancer. J. Cell. Biochem. 2013, 114, 967-974. [CrossRef] [PubMed]

35. Weidner, N.; Semple, J.P.; Welch, W.R.; Folkman, J. Tumor Angiogenesis and Metastasis—Correlation in Invasive Breast Carcinoma. N. Engl. J. Med. 1991, 324, 1-8. [CrossRef] [PubMed]

36. Jafari Nivlouei, S.; Soltani, M.; Carvalho, J.; Travasso, R.; Salimpour, M.R.; Shirani, E. Multiscale modeling of tumor growth and angiogenesis: Evaluation of tumor-targeted therapy. PLoS Comput. Biol. 2021, 17, e1009081. [CrossRef] [PubMed]

37. Phillips, C.M.; Lima, E.A.B.F.; Woodall, R.T.; Brock, A.; Yankeelov, T.E. A hybrid model of tumor growth and angiogenesis: In silico experiments. PLoS ONE 2020, 15, e0231137. [CrossRef]

38. Shirinifard, A.; Gens, J.S.; Zaitlen, B.L.; Popławski, N.J.; Swat, M.; Glazier, J.A. 3D Multi-Cell Simulation of Tumor Growth and Angiogenesis. PLoS ONE 2009, 4, e7190. [CrossRef] [PubMed]

39. Cao, Y. Tumor angiogenesis and molecular targets for therapy. Front. Biosci. 2009, 14, 3962. [CrossRef]

40. Folkman, J. What Is the Evidence That Tumors Are Angiogenesis Dependent? J. Natl. Cancer Inst. 1990, 82, 4-6. [CrossRef]

41. De Palma, M.; Biziato, D.; Petrova, T.V. Microenvironmental regulation of tumour angiogenesis. Nat. Rev. Cancer 2017, 17, 457-474. [CrossRef] [PubMed]

42. Zhao, H.; Wu, L.; Yan, G.; Chen, Y.; Zhou, M.; Wu, Y.; Li, Y. Inflammation and tumor progression: Signaling pathways and targeted intervention. Signal Transduct. Target. Ther. 2021, 6, 263. [CrossRef] [PubMed]

43. Kammerer, T.; Faihs, V.; Hulde, N.; Stangl, M.; Brettner, F.; Rehm, M.; Horstmann, M.; Kröpfl, J.; Spengler, C.; Kreth, S.; et al Hypoxic-Inflammatory Responses under Acute Hypoxia: In Vitro Experiments and Prospective Observational Expedition Trial Int. J. Mol. Sci. 2020, 21, 1034. [CrossRef] [PubMed]

44. Eruslanov, E.B.; Singhal, S.; Albelda, S.M. Mouse versus Human Neutrophils in Cancer: A Major Knowledge Gap. Trends in Cancer 2017, 3, 149-160. [CrossRef]

45. Summers, C.; Rankin, S.M.; Condliffe, A.M.; Singh, N.; Peters, A.M.; Chilvers, E.R. Neutrophil kinetics in health and disease. Trends Immunol. 2010, 31, 318-324. [CrossRef]

46. Jaillon, S.; Ponzetta, A.; Di Mitri, D.; Santoni, A.; Bonecchi, R.; Mantovani, A. Neutrophil diversity and plasticity in tumour progression and therapy. Nat. Rev. Cancer 2020, 20, 485-503. [CrossRef]

47. Ng, L.G.; Ostuni, R.; Hidalgo, A. Heterogeneity of neutrophils. Nat. Rev. Immunol. 2019, 19, 255-265. [CrossRef]

48. Hassani, M.; Hellebrekers, P.; Chen, N.; Aalst, C.; Bongers, S.; Hietbrink, F.; Koenderman, L.; Vrisekoop, N. On the origin of low-density neutrophils. J. Leukoc. Biol. 2020, 107, 809-818. [CrossRef]

49. Jablonska, J.; Granot, Z. Neutrophil, quo vadis? J. Leukoc. Biol. 2017, 102, 685-688. [CrossRef]

50. Granot, Z.; Jablonska, J. Distinct Functions of Neutrophil in Cancer and Its Regulation. Mediators Inflamm. 2015, $2015,701067$. [CrossRef]

51. Andzinski, L.; Kasnitz, N.; Stahnke, S.; Wu, C.-F.; Gereke, M.; von Köckritz-Blickwede, M.; Schilling, B.; Brandau, S.; Weiss, S.; Jablonska, J. Type IIFNs induce anti-tumor polarization of tumor associated neutrophils in mice and human. Int. J. Cancer 2016, 138, 1982-1993. [CrossRef] [PubMed]

52. Pylaeva, E.; Lang, S.; Jablonska, J. The Essential Role of Type I Interferons in Differentiation and Activation of Tumor-Associated Neutrophils. Front. Immunol. 2016, 7, 629. [CrossRef]

53. Mülling, K.; Fischer, A.J.; Siakaeva, E.; Richter, M.; Bordbari, S.; Spyra, I.; Köster, C.; Hermann, D.M.; Gunzer, M.; FelderhoffMüser, U.; et al. Neutrophil dynamics, plasticity and function in acute neurodegeneration following neonatal hypoxia-ischemia. Brain Behav. Immun. 2021, 92, 232-242. [CrossRef]

54. Siakaeva, E.; Pylaeva, E.; Spyra, I.; Bordbari, S.; Höing, B.; Kürten, C.; Lang, S.; Jablonska, J. Neutrophil Maturation and Survival Is Controlled by IFN-Dependent Regulation of NAMPT Signaling. Int. J. Mol. Sci. 2019, 20, 5584. [CrossRef] [PubMed]

55. Andzinski, L.; Wu, C.-F.; Lienenklaus, S.; Kröger, A.; Weiss, S.; Jablonska, J. Delayed apoptosis of tumor associated neutrophils in the absence of endogenous IFN- $\beta$. Int. J. Cancer 2014, 136, 572-583. [CrossRef] [PubMed] 
56. Shaul, M.E.; Fridlender, Z.G. Tumour-associated neutrophils in patients with cancer. Nat. Rev. Clin. Oncol. 2019, 16, 601-620. [CrossRef] [PubMed]

57. Uribe-Querol, E.; Rosales, C. Neutrophils in Cancer: Two Sides of the Same Coin. J. Immunol. Res. 2015, 2015, 983698. [CrossRef] [PubMed]

58. Kargl, J.; Busch, S.E.; Yang, G.H.Y.; Kim, K.-H.; Hanke, M.L.; Metz, H.E.; Hubbard, J.J.; Lee, S.M.; Madtes, D.K.; McIntosh, M.W.; et al. Neutrophils dominate the immune cell composition in non-small cell lung cancer. Nat. Commun. 2017, 8, 14381. [CrossRef]

59. Galdiero, M.R.; Bianchi, P.; Grizzi, F.; Di Caro, G.; Basso, G.; Ponzetta, A.; Bonavita, E.; Barbagallo, M.; Tartari, S.; Polentarutti, N.; et al. Occurrence and significance of tumor-associated neutrophils in patients with colorectal cancer. Int. J. Cancer 2016, 139, 446-456. [CrossRef] [PubMed]

60. Nagaraj, S.; Schrum, A.G.; Cho, H.-I.; Celis, E.; Gabrilovich, D.I. Mechanism of T Cell Tolerance Induced by Myeloid-Derived Suppressor Cells. J. Immunol. 2010, 184, 3106-3116. [CrossRef]

61. Mantovani, A.; Cassatella, M.A.; Costantini, C.; Jaillon, S. Neutrophils in the activation and regulation of innate and adaptive immunity. Nat. Rev. Immunol. 2011, 11, 519-531. [CrossRef]

62. Cortez-Retamozo, V.; Etzrodt, M.; Newton, A.; Rauch, P.J.; Chudnovskiy, A.; Berger, C.; Ryan, R.J.H.; Iwamoto, Y.; Marinelli, B.; Gorbatov, R.; et al. Origins of tumor-associated macrophages and neutrophils. Proc. Natl. Acad. Sci. USA 2012, 109, $2491-2496$. [CrossRef] [PubMed]

63. Kim, J.; Bae, J.-S. Tumor-Associated Macrophages and Neutrophils in Tumor Microenvironment. Mediators Inflamm. 2016, 2016, 6058147. [CrossRef] [PubMed]

64. Michael, M.; Goldstein, D.; Clarke, S.J.; Milner, A.D.; Beale, P.; Friedlander, M.; Mitchell, P. Prognostic Factors Predictive of Response and Survival to a Modified FOLFOX Regimen: Importance of an Increased Neutrophil Count. Clin. Colorectal Cancer 2006, 6, 297-304. [CrossRef]

65. Ou, Q.; Cheng, J.; Zhang, L.; Wang, H.; Wang, W.; Ma, Y. The prognostic value of pretreatment neutrophil-to-lymphocyte ratio in breast cancer: Deleterious or advantageous? Tumor Biol. 2017, 39, 101042831770621. [CrossRef] [PubMed]

66. Cupp, M.A.; Cariolou, M.; Tzoulaki, I.; Aune, D.; Evangelou, E.; Berlanga-Taylor, A.J. Neutrophil to lymphocyte ratio and cancer prognosis: An umbrella review of systematic reviews and meta-analyses of observational studies. BMC Med. 2020, 18, 360. [CrossRef] [PubMed]

67. Corbeau, I.; Jacot, W.; Guiu, S. Neutrophil to Lymphocyte Ratio as Prognostic and Predictive Factor in Breast Cancer Patients: A Systematic Review. Cancers 2020, 12, 958. [CrossRef]

68. Cho, H.; Hur, H.W.; Kim, S.W.; Kim, S.H.; Kim, J.H.; Kim, Y.T.; Lee, K. Pre-treatment neutrophil to lymphocyte ratio is elevated in epithelial ovarian cancer and predicts survival after treatment. Cancer Immunol. Immunother. 2009, 58, 15-23. [CrossRef] [PubMed]

69. Charles, K.A.; Kulbe, H.; Soper, R.; Escorcio-Correia, M.; Lawrence, T.; Schultheis, A.; Chakravarty, P.; Thompson, R.G.; Kollias, G.; Smyth, J.F.; et al. The tumor-promoting actions of TNF- $\alpha$ involve TNFR1 and IL-17 in ovarian cancer in mice and humans. J. Clin. Investig. 2009, 119, 3011-3023. [CrossRef]

70. Dentelli, P.; Rosso, A.; Olgasi, C.; Camussi, G.; Brizzi, M.F. IL-3 is a novel target to interfere with tumor vasculature. Oncogene 2011, 30, 4930-4940. [CrossRef]

71. Mizukami, Y.; Jo, W.-S.; Duerr, E.-M.; Gala, M.; Li, J.; Zhang, X.; Zimmer, M.A.; Iliopoulos, O.; Zukerberg, L.R.; Kohgo, Y.; et al. Induction of interleukin-8 preserves the angiogenic response in HIF-1 $\alpha$-deficient colon cancer cells. Nat. Med. 2005, 11, $992-997$. [CrossRef]

72. Jablonska, J.; Wu, C.-F.; Andzinski, L.; Leschner, S.; Weiss, S. CXCR2-mediated tumor-associated neutrophil recruitment is regulated by IFN- $\beta$. Int. J. Cancer 2014, 134, 1346-1358. [CrossRef]

73. Liu, L.; Liu, Y.; Yan, X.; Zhou, C.; Xiong, X. The role of granulocyte colony-stimulating factor in breast cancer development: A review. Mol. Med. Rep. 2020, 21, 2019-2029. [CrossRef]

74. Theyab, A.; Algahtani, M.; Alsharif, K.F.; Hawsawi, Y.M.; Alghamdi, A.; Alghamdi, A.; Akinwale, J. New insight into the mechanism of granulocyte colony-stimulating factor (G-CSF) that induces the mobilization of neutrophils. Hematology 2021, 26, 628-636. [CrossRef]

75. Fridlender, Z.G.; Sun, J.; Kim, S.; Kapoor, V.; Cheng, G.; Ling, L.; Worthen, G.S.; Albelda, S.M. Polarization of Tumor-Associated Neutrophil Phenotype by TGF- $\beta$ : “N1" versus “N2" TAN. Cancer Cell 2009, 16, 183-194. [CrossRef] [PubMed]

76. Giese, M.A.; Hind, L.E.; Huttenlocher, A. Neutrophil plasticity in the tumor microenvironment. Blood 2019, 133, 2159-2167. [CrossRef] [PubMed]

77. Nan, J.; Xing, Y.-F.; Hu, B.; Tang, J.-X.; Dong, H.-M.; He, Y.-M.; Ruan, D.-Y.; Ye, Q.-J.; Cai, J.-R.; Ma, X.-K.; et al. Endoplasmic reticulum stress induced LOX-1 + CD15 + polymorphonuclear myeloid-derived suppressor cells in hepatocellular carcinoma. Immunology 2018, 154, 144-155. [CrossRef]

78. Condamine, T.; Dominguez, G.A.; Youn, J.-I.; Kossenkov, A.V.; Mony, S.; Alicea-Torres, K.; Tcyganov, E.; Hashimoto, A.; Nefedova, Y.; Lin, C.; et al. Lectin-type oxidized LDL receptor-1 distinguishes population of human polymorphonuclear myeloid-derived suppressor cells in cancer patients. Sci. Immunol. 2016, 1, aaf8943. [CrossRef] [PubMed]

79. Patel, S.; Fu, S.; Mastio, J.; Dominguez, G.A.; Purohit, A.; Kossenkov, A.; Lin, C.; Alicea-Torres, K.; Sehgal, M.; Nefedova, Y.; et al. Unique pattern of neutrophil migration and function during tumor progression. Nat. Immunol. 2018, 19, 1236-1247. [CrossRef] [PubMed] 
80. Mishalian, I.; Bayuh, R.; Levy, L.; Zolotarov, L.; Michaeli, J.; Fridlender, Z.G. Tumor-associated neutrophils (TAN) develop pro-tumorigenic properties during tumor progression. Cancer Immunol. Immunother. 2013, 62, 1745-1756. [CrossRef] [PubMed]

81. Xiong, S.; Dong, L.; Cheng, L. Neutrophils in cancer carcinogenesis and metastasis. J. Hematol. Oncol. 2021, 14, 173. [CrossRef] [PubMed]

82. Singhal, S.; Bhojnagarwala, P.S.; O’Brien, S.; Moon, E.K.; Garfall, A.L.; Rao, A.S.; Quatromoni, J.G.; Stephen, T.L.; Litzky, L.; Deshpande, C.; et al. Origin and Role of a Subset of Tumor-Associated Neutrophils with Antigen-Presenting Cell Features in Early-Stage Human Lung Cancer. Cancer Cell 2016, 30, 120-135. [CrossRef] [PubMed]

83. Eruslanov, E.B.; Bhojnagarwala, P.S.; Quatromoni, J.G.; Stephen, T.L.; Ranganathan, A.; Deshpande, C.; Akimova, T.; Vachani, A.; Litzky, L.; Hancock, W.W.; et al. Tumor-associated neutrophils stimulate T cell responses in early-stage human lung cancer. J. Clin. Investig. 2014, 124, 5466-5480. [CrossRef] [PubMed]

84. Siwicki, M.; Pittet, M.J. Versatile neutrophil functions in cancer. Semin. Immunol. 2021; in press. [CrossRef]

85. Blaisdell, A.; Crequer, A.; Columbus, D.; Daikoku, T.; Mittal, K.; Dey, S.K.; Erlebacher, A. Neutrophils Oppose Uterine Epithelial Carcinogenesis via Debridement of Hypoxic Tumor Cells. Cancer Cell 2015, 28, 785-799. [CrossRef]

86. Sagiv, J.Y.; Michaeli, J.; Assi, S.; Mishalian, I.; Kisos, H.; Levy, L.; Damti, P.; Lumbroso, D.; Polyansky, L.; Sionov, R.V.; et al Phenotypic Diversity and Plasticity in Circulating Neutrophil Subpopulations in Cancer. Cell Rep. 2015, 10, 562-573. [CrossRef]

87. Masucci, M.T.; Minopoli, M.; Carriero, M.V. Tumor Associated Neutrophils. Their Role in Tumorigenesis, Metastasis, Prognosis and Therapy. Front. Oncol. 2019, 9, 1146. [CrossRef] [PubMed]

88. Shaul, M.E.; Fridlender, Z.G. Cancer-related circulating and tumor-associated neutrophils-subtypes, sources and function. FEBS J. 2018, 285, 4316-4342. [CrossRef] [PubMed]

89. Domnich, M.; Riedesel, J.; Pylaeva, E.; Kürten, C.H.L.; Buer, J.; Lang, S.; Jablonska, J. Oral Neutrophils: Underestimated Players in Oral Cancer. Front. Immunol. 2020, 11, 565683. [CrossRef] [PubMed]

90. Wu, C.-F.; Andzinski, L.; Kasnitz, N.; Kröger, A.; Klawonn, F.; Lienenklaus, S.; Weiss, S.; Jablonska, J. The lack of type I interferon induces neutrophil-mediated pre-metastatic niche formation in the mouse lung. Int. J. Cancer 2015, 137, 837-847. [CrossRef]

91. Fridlender, Z.G.; Albelda, S.M. Tumor-associated neutrophils: Friend or foe? Carcinogenesis 2012, 33, 949-955. [CrossRef] [PubMed]

92. Coffelt, S.B.; Kersten, K.; Doornebal, C.W.; Weiden, J.; Vrijland, K.; Hau, C.-S.; Verstegen, N.J.M.; Ciampricotti, M.; Hawinkels, L.J.A.C.; Jonkers, J.; et al. IL-17-producing $\gamma \delta \mathrm{T}$ cells and neutrophils conspire to promote breast cancer metastasis. Nature 2015, 522, 345-348. [CrossRef] [PubMed]

93. Gabrilovich, D.I.; Ostrand-Rosenberg, S.; Bronte, V. Coordinated regulation of myeloid cells by tumours. Nat. Rev. Immunol. 2012, 12, 253-268. [CrossRef]

94. Cheng, Y.; Li, H.; Deng, Y.; Tai, Y.; Zeng, K.; Zhang, Y.; Liu, W.; Zhang, Q.; Yang, Y. Cancer-associated fibroblasts induce PDL1+ neutrophils through the IL6-STAT3 pathway that foster immune suppression in hepatocellular carcinoma. Cell Death Dis. 2018, 9, 422. [CrossRef] [PubMed]

95. Xu, W.; Dong, J.; Zheng, Y.; Zhou, J.; Yuan, Y.; Ta, H.M.; Miller, H.E.; Olson, M.; Rajasekaran, K.; Ernstoff, M.S.; et al. ImmuneCheckpoint Protein VISTA Regulates Antitumor Immunity by Controlling Myeloid Cell-Mediated Inflammation and Immunosuppression. Cancer Immunol. Res. 2019, 7, 1497-1510. [CrossRef] [PubMed]

96. Yan, B.; Wei, J.-J.; Yuan, Y.; Sun, R.; Li, D.; Luo, J.; Liao, S.-J.; Zhou, Y.-H.; Shu, Y.; Wang, Q.; et al. IL-6 Cooperates with G-CSF To Induce Protumor Function of Neutrophils in Bone Marrow by Enhancing STAT3 Activation. J. Immunol. 2013, 190, 5882-5893. [CrossRef] [PubMed]

97. Nozawa, H.; Chiu, C.; Hanahan, D. Infiltrating neutrophils mediate the initial angiogenic switch in a mouse model of multistage carcinogenesis. Proc. Natl. Acad. Sci. USA 2006, 103, 12493-12498. [CrossRef]

98. Zhao, Y.; Huang, X.; Ding, T.W.; Gong, Z. Enhanced angiogenesis, hypoxia and neutrophil recruitment during Myc-induced liver tumorigenesis in zebrafish. Sci. Rep. 2016, 6, 31952. [CrossRef]

99. Caruso, R.A.; Bonanno, A.; Finocchiaro, G.; Cavaliere, R.; Gitto, G.; Plutino, F.M.; Quattrocchi, E.; Cuppari, M.C.; Fabiano, V.; Basile, G. Ultrastructural Observations on Inflammatory Angiogenesis in Gastric Carcinomas with Massive Neutrophil Infiltration. Ultrastruct. Pathol. 2009, 33, 1-5. [CrossRef]

100. Sano, M.; Takahashi, R.; Ijichi, H.; Ishigaki, K.; Yamada, T.; Miyabayashi, K.; Kimura, G.; Mizuno, S.; Kato, H.; Fujiwara, H.; et al. Blocking VCAM-1 inhibits pancreatic tumour progression and cancer-associated thrombosis/thromboembolism. Gut 2021, 70, 1713-1723. [CrossRef]

101. Nagaoka, K.; Shirai, M.; Taniguchi, K.; Hosoi, A.; Sun, C.; Kobayashi, Y.; Maejima, K.; Fujita, M.; Nakagawa, H.; Nomura, S.; et al. Deep immunophenotyping at the single-cell level identifies a combination of anti-IL-17 and checkpoint blockade as an effective treatment in a preclinical model of data-guided personalized immunotherapy. J. Immunother. Cancer 2020, 8, e001358. [CrossRef]

102. Li, T.; Tan, K.S.; Tu, Y.Y.; Zhao, L.; Liu, J.; Ong, H.H.; Wang, D.Y.; Shi, L. Overexpression of Neutrophil MMP-9 and HIF-1 $\alpha$ May Contribute to the Finger-Like Projections Formation and Histo-Pathogenesis in Nasal Inverted Papilloma. J. Inflamm. Res. 2021, 14, 2979-2991. [CrossRef]

103. Pylaeva, E.; Spyra, I.; Bordbari, S.; Lang, S.; Jablonska, J. Transfer of Manipulated Tumor-associated Neutrophils into TumorBearing Mice to Study their Angiogenic Potential In Vivo. J. Vis. Exp. 2019; in press. [CrossRef] 
104. Pylaeva, E.; Harati, M.D.; Spyra, I.; Bordbari, S.; Strachan, S.; Thakur, B.K.; Höing, B.; Franklin, C.; Skokowa, J.; Welte, K.; et al. NAMPT signaling is critical for the proangiogenic activity of tumor-associated neutrophils. Int. J. Cancer 2019, 144, 136-149. [CrossRef] [PubMed]

105. Bordbari, S.; Mörchen, B.; Pylaeva, E.; Siakaeva, E.; Spyra, I.; Domnich, M.; Droege, F.; Kanaan, O.; Lang, K.S.; Schadendorf, D.; et al. SIRT1-mediated deacetylation of FOXO3a transcription factor supports pro-angiogenic activity of interferon-deficient tumor-associated neutrophils. Int. J. Cancer, 2021; in press. [CrossRef] [PubMed]

106. Teuwen, L.-A.; De Rooij, L.P.M.H.; Cuypers, A.; Rohlenova, K.; Dumas, S.J.; García-Caballero, M.; Meta, E.; Amersfoort, J.; Taverna, F.; Becker, L.M.; et al. Tumor vessel co-option probed by single-cell analysis. Cell Rep. 2021, 35, 109253. [CrossRef] [PubMed]

107. Tsai, Y.-M.; Wu, K.-L.; Liu, Y.-W.; Chang, W.-A.; Huang, Y.-C.; Chang, C.-Y.; Tsai, P.-H.; Liao, S.-H.; Hung, J.-Y.; Hsu, Y.-L. Cooperation Between Cancer and Fibroblasts in Vascular Mimicry and N2-Type Neutrophil Recruitment via Notch2-Jagged1 Interaction in Lung Cancer. Front. Oncol. 2021, 11, 696931. [CrossRef] [PubMed]

108. Palmieri, V.; Lazaris, A.; Mayer, T.Z.; Petrillo, S.K.; Alamri, H.; Rada, M.; Jarrouj, G.; Park, W.; Gao, Z.; McDonald, P.P.; et al. Neutrophils expressing lysyl oxidase-like 4 protein are present in colorectal cancer liver metastases resistant to anti-angiogenic therapy. J. Pathol. 2020, 251, 213-223. [CrossRef] [PubMed]

109. Liang, W.; Ferrara, N. The Complex Role of Neutrophils in Tumor Angiogenesis and Metastasis. Cancer Immunol. Res. 2016, 4 , 83-91. [CrossRef]

110. Grenier, A.; Chollet-Martin, S.; Crestani, B.; Delarche, C.; El Benna, J.; Boutten, A.; Andrieu, V.; Durand, G.; Gougerot-Pocidalo, M.-A.; Aubier, M.; et al. Presence of a mobilizable intracellular pool of hepatocyte growth factor in human polymorphonuclear neutrophils. Blood 2002, 99, 2997-3004. [CrossRef]

111. Shojaei, F.; Singh, M.; Thompson, J.D.; Ferrara, N. Role of Bv8 in neutrophil-dependent angiogenesis in a transgenic model of cancer progression. Proc. Natl. Acad. Sci. USA 2008, 105, 2640-2645. [CrossRef] [PubMed]

112. Gaudry, M.; Brégerie, O.; Andrieu, V.; El Benna, J.; Pocidalo, M.-A.; Hakim, J. Intracellular Pool of Vascular Endothelial Growth Factor in Human Neutrophils. Blood 1997, 90, 4153-4161. [CrossRef]

113. Nadkarni, S.; Smith, J.; Sferruzzi-Perri, A.N.; Ledwozyw, A.; Kishore, M.; Haas, R.; Mauro, C.; Williams, D.J.; Farsky, S.H.P.; Marelli-Berg, F.M.; et al. Neutrophils induce proangiogenic T cells with a regulatory phenotype in pregnancy. Proc. Natl. Acad. Sci. USA 2016, 113, E8415-E8424. [CrossRef] [PubMed]

114. Zou, J.-M.; Qin, J.; Li, Y.-C.; Wang, Y.; Li, D.; Shu, Y.; Luo, C.; Wang, S.-S.; Chi, G.; Guo, F.; et al. IL-35 induces N2 phenotype of neutrophils to promote tumor growth. Oncotarget 2017, 8, 33501-33514. [CrossRef] [PubMed]

115. Queen, M.M.; Ryan, R.E.; Holzer, R.G.; Keller-Peck, C.R.; Jorcyk, C.L. Breast Cancer Cells Stimulate Neutrophils to Produce Oncostatin M: Potential Implications for Tumor Progression. Cancer Res. 2005, 65, 8896-8904. [CrossRef]

116. Gordon-Weeks, A.N.; Lim, S.Y.; Yuzhalin, A.E.; Jones, K.; Markelc, B.; Kim, K.J.; Buzzelli, J.N.; Fokas, E.; Cao, Y.; Smart, S.; et al Neutrophils promote hepatic metastasis growth through fibroblast growth factor 2-dependent angiogenesis in mice. Hepatology 2017, 65, 1920-1935. [CrossRef] [PubMed]

117. Wutschka, J.; Kast, B.; Sator-Schmitt, M.; Appak-Baskoy, S.; Hess, J.; Sinn, H.-P.; Angel, P.; Schorpp-Kistner, M. JUNB suppresses distant metastasis by influencing the initial metastatic stage. Clin. Exp. Metastasis 2021, 38, 411-423. [CrossRef]

118. Shojaei, F.; Wu, X.; Malik, A.K.; Zhong, C.; Baldwin, M.E.; Schanz, S.; Fuh, G.; Gerber, H.-P.; Ferrara, N. Tumor refractoriness to anti-VEGF treatment is mediated by CD11b+Gr1+ myeloid cells. Nat. Biotechnol. 2007, 25, 911-920. [CrossRef]

119. Jung, K.; Heishi, T.; Khan, O.F.; Kowalski, P.S.; Incio, J.; Rahbari, N.N.; Chung, E.; Clark, J.W.; Willett, C.G.; Luster, A.D.; et al Ly6Clo monocytes drive immunosuppression and confer resistance to anti-VEGFR2 cancer therapy. J. Clin. Investig. 2017, 127, 3039-3051. [CrossRef] [PubMed]

120. Kusumanto, Y.H.; Dam, W.A.; Hospers, G.A.P.; Meijer, C.; Mulder, N.H. Platelets and Granulocytes, in Particular the Neutrophils, Form Important Compartments for Circulating Vascular Endothelial Growth Factor. Angiogenesis 2003, 6, 283-287. [CrossRef] [PubMed]

121. Jablonska, E.; Piotrowski, L.; Jablonski, J.; Grabowska, Z. VEGF in the culture of PMN and the serum in oral cavity cancer patients. Oral Oncol. 2002, 38, 605-609. [CrossRef]

122. Gong, Y.; Koh, D.-R. Neutrophils promote inflammatory angiogenesis via release of preformed VEGF in an in vivo corneal model. Cell Tissue Res. 2010, 339, 437-448. [CrossRef]

123. Lee, T.-H.; Avraham, H.; Lee, S.-H.; Avraham, S. Vascular Endothelial Growth Factor Modulates Neutrophil Transendothelial Migration via Up-regulation of Interleukin-8 in Human Brain Microvascular Endothelial Cells. J. Biol. Chem. 2002, 277, 1044510451. [CrossRef]

124. Ardi, V.C.; Van den Steen, P.E.; Opdenakker, G.; Schweighofer, B.; Deryugina, E.I.; Quigley, J.P. Neutrophil MMP-9 Proenzyme, Unencumbered by TIMP-1, Undergoes Efficient Activation in Vivo and Catalytically Induces Angiogenesis via a Basic Fibroblast Growth Factor (FGF-2)/FGFR-2 Pathway. J. Biol. Chem. 2009, 284, 25854-25866. [CrossRef] [PubMed]

125. Ishai-Michaeli, R.; Eldor, A.; Vlodavsky, I. Heparanase activity expressed by platelets, neutrophils, and lymphoma cells releases active fibroblast growth factor from extracellular matrix. Cell Regul. 1990, 1, 833-842. [CrossRef] [PubMed]

126. Zarling, J.M.; Shoyab, M.; Marquardt, H.; Hanson, M.B.; Lioubin, M.N.; Todaro, G.J. Oncostatin M: A growth regulator produced by differentiated histiocytic lymphoma cells. Proc. Natl. Acad. Sci. USA 1986, 83, 9739-9743. [CrossRef] [PubMed] 
127. Liu, J.; Hadjokas, N.; Mosley, B.; Estrov, Z.; Spence, M.J.; Vestal, R.E. Oncostatin M-specific receptor expression and function in regulating cell proliferation of normal and malignant mammary epithelial cells. Cytokine 1998, 10, 295-302. [CrossRef] [PubMed]

128. Numasaki, M.; Watanabe, M.; Suzuki, T.; Takahashi, H.; Nakamura, A.; McAllister, F.; Hishinuma, T.; Goto, J.; Lotze, M.T.; Kolls, J.K.; et al. IL-17 Enhances the Net Angiogenic Activity and In Vivo Growth of Human Non-Small Cell Lung Cancer in SCID Mice through Promoting CXCR-2-Dependent Angiogenesis. J. Immunol. 2005, 175, 6177-6189. [CrossRef] [PubMed]

129. Stetler-Stevenson, W.G.; Yu, A.E. Proteases in invasion: Matrix metalloproteinases. Semin. Cancer Biol. 2001, 11, 143-152. [CrossRef]

130. Duffy, M.J.; Maguire, T.M.; Hill, A.; McDermott, E.; O’Higgins, N. Metalloproteinases: Role in breast carcinogenesis, invasion and metastasis. Breast Cancer Res. 2000, 2, 252-257. [CrossRef]

131. Quintero-Fabián, S.; Arreola, R.; Becerril-Villanueva, E.; Torres-Romero, J.C.; Arana-Argáez, V.; Lara-Riegos, J.; Ramírez-Camacho, M.A.; Alvarez-Sánchez, M.E. Role of Matrix Metalloproteinases in Angiogenesis and Cancer. Front. Oncol. 2019, 9, 1370. [CrossRef]

132. Bergers, G.; Benjamin, L.E. Tumorigenesis and the angiogenic switch. Nat. Rev. Cancer 2003, 3, 401-410. [CrossRef]

133. Deryugina, E.I.; Zajac, E.; Juncker-Jensen, A.; Kupriyanova, T.A.; Welter, L.; Quigley, J.P. Tissue-Infiltrating Neutrophils Constitute the Major In Vivo Source of Angiogenesis-Inducing MMP-9 in the Tumor Microenvironment. Neoplasia 2014, 16, 771-788. [CrossRef]

134. Tazzyman, S.; Lewis, C.E.; Murdoch, C. Neutrophils: Key mediators of tumour angiogenesis. Int. J. Exp. Pathol. 2009, 90, $222-231$. [CrossRef]

135. Hollborn, M.; Stathopoulos, C.; Steffen, A.; Wiedemann, P.; Kohen, L.; Bringmann, A. Positive Feedback Regulation between MMP-9 and VEGF in Human RPE Cells. Investig. Opthalmology Vis. Sci. 2007, 48, 4360-4367. [CrossRef]

136. Christoffersson, G.; Vågesjö, E.; Vandooren, J.; Lidén, M.; Massena, S.; Reinert, R.B.; Brissova, M.; Powers, A.C.; Opdenakker, G.; Phillipson, M. VEGF-A recruits a proangiogenic MMP-9-delivering neutrophil subset that induces angiogenesis in transplanted hypoxic tissue. Blood 2012, 120, 4653-4662. [CrossRef]

137. Massena, S.; Christoffersson, G.; Vågesjö, E.; Seignez, C.; Gustafsson, K.; Binet, F.; Herrera Hidalgo, C.; Giraud, A.; Lomei, J.; Weström, S.; et al. Identification and characterization of VEGF-A-responsive neutrophils expressing CD49d, VEGFR1, and CXCR4 in mice and humans. Blood 2015, 126, 2016-2026. [CrossRef] [PubMed]

138. Tan, K.W.; Chong, S.Z.; Wong, F.H.S.; Evrard, M.; Tan, S.M.-L.; Keeble, J.; Kemeny, D.M.; Ng, L.G.; Abastado, J.-P.; Angeli, V. Neutrophils contribute to inflammatory lymphangiogenesis by increasing VEGF-A bioavailability and secreting VEGF-D. Blood 2013, 122, 3666-3677. [CrossRef] [PubMed]

139. Li, T.-J.; Jiang, Y.-M.; Hu, Y.-F.; Huang, L.; Yu, J.; Zhao, L.-Y.; Deng, H.-J.; Mou, T.-Y.; Liu, H.; Yang, Y.; et al. Interleukin-17Producing Neutrophils Link Inflammatory Stimuli to Disease Progression by Promoting Angiogenesis in Gastric Cancer. Clin. Cancer Res. 2017, 23, 1575-1585. [CrossRef] [PubMed]

140. Bekes, E.M.; Schweighofer, B.; Kupriyanova, T.A.; Zajac, E.; Ardi, V.C.; Quigley, J.P.; Deryugina, E.I. Tumor-Recruited Neutrophils and Neutrophil TIMP-Free MMP-9 Regulate Coordinately the Levels of Tumor Angiogenesis and Efficiency of Malignant Cell Intravasation. Am. J. Pathol. 2011, 179, 1455-1470. [CrossRef] [PubMed]

141. Yan, B.; Wu, X. G-CSF induces production of Bv8 in murine bone marrow neutrophils and promotes tumor growth and angiogenesis of U14 murine cervical cancer cell line. Ann. Oncol. 2017, 28 (Suppl. 10), x91. [CrossRef]

142. Shojaei, F.; Wu, X.; Zhong, C.; Yu, L.; Liang, X.-H.; Yao, J.; Blanchard, D.; Bais, C.; Peale, F.V.; van Bruggen, N.; et al. Bv8 regulates myeloid-cell-dependent tumour angiogenesis. Nature 2007, 450, 825-831. [CrossRef] [PubMed]

143. Gebhardt, C.; Németh, J.; Angel, P.; Hess, J. S100A8 and S100A9 in inflammation and cancer. Biochem. Pharmacol. 2006, 72, 1622-1631. [CrossRef]

144. Zhong, C.; Qu, X.; Tan, M.; Meng, Y.G.; Ferrara, N. Characterization and Regulation of Bv8 in Human Blood Cells. Clin. Cancer Res. 2009, 15, 2675-2684. [CrossRef] [PubMed]

145. Itatani, Y.; Yamamoto, T.; Zhong, C.; Molinolo, A.A.; Ruppel, J.; Hegde, P.; Taketo, M.M.; Ferrara, N. Suppressing neutrophildependent angiogenesis abrogates resistance to anti-VEGF antibody in a genetic model of colorectal cancer. Proc. Natl. Acad. Sci. USA 2020, 117, 21598-21608. [CrossRef] [PubMed]

146. Shojaei, F.; Wu, X.; Qu, X.; Kowanetz, M.; Yu, L.; Tan, M.; Meng, Y.G.; Ferrara, N. G-CSF-initiated myeloid cell mobilization and angiogenesis mediate tumor refractoriness to anti-VEGF therapy in mouse models. Proc. Natl. Acad. Sci. USA 2009, 106, 6742-6747. [CrossRef] [PubMed]

147. Zou, S.; Tong, Q.; Liu, B.; Huang, W.; Tian, Y.; Fu, X. Targeting STAT3 in Cancer Immunotherapy. Mol. Cancer 2020, $19,145$. [CrossRef]

148. Ma, J.; Qin, L.; Li, X. Role of STAT3 signaling pathway in breast cancer. Cell Commun. Signal. 2020, 18, 33. [CrossRef] [PubMed]

149. Yu, H.; Kortylewski, M.; Pardoll, D. Crosstalk between cancer and immune cells: Role of STAT3 in the tumour microenvironment. Nat. Rev. Immunol. 2007, 7, 41-51. [CrossRef]

150. Nguyen-Jackson, H.; Panopoulos, A.D.; Zhang, H.; Li, H.S.; Watowich, S.S. STAT3 controls the neutrophil migratory response to CXCR2 ligands by direct activation of G-CSF-induced CXCR2 expression and via modulation of CXCR2 signal transduction. Blood 2010, 115, 3354-3363. [CrossRef]

151. McLemore, M.L.; Grewal, S.; Liu, F.; Archambault, A.; Poursine-Laurent, J.; Haug, J.; Link, D.C. STAT-3 Activation Is Required for Normal G-CSF-Dependent Proliferation and Granulocytic Differentiation. Immunity 2001, 14, 193-204. [CrossRef] 
152. Panopoulos, A.D.; Zhang, L.; Snow, J.W.; Jones, D.M.; Smith, A.M.; El Kasmi, K.C.; Liu, F.; Goldsmith, M.A.; Link, D.C.; Murray, P.J.; et al. STAT3 governs distinct pathways in emergency granulopoiesis and mature neutrophils. Blood 2006, 108, 3682-3690. [CrossRef]

153. Kujawski, M.; Kortylewski, M.; Lee, H.; Herrmann, A.; Kay, H.; Yu, H. Stat3 mediates myeloid cell-dependent tumor angiogenesis in mice. J. Clin. Investig. 2008, 118, 3367-3377. [CrossRef] [PubMed]

154. Qu, X.; Zhuang, G.; Yu, L.; Meng, G.; Ferrara, N. Induction of Bv8 Expression by Granulocyte Colony-stimulating Factor in CD11b+Gr1+ Cells. J. Biol. Chem. 2012, 287, 19574-19584. [CrossRef] [PubMed]

155. Aldabbous, L.; Abdul-Salam, V.; McKinnon, T.; Duluc, L.; Pepke-Zaba, J.; Southwood, M.; Ainscough, A.J.; Hadinnapola, C.; Wilkins, M.R.; Toshner, M.; et al. Neutrophil Extracellular Traps Promote Angiogenesis. Arterioscler. Thromb. Vasc. Biol. 2016, 36, 2078-2087. [CrossRef]

156. Jung, H.S.; Gu, J.; Kim, J.-E.; Nam, Y.; Song, J.W.; Kim, H.K. Cancer cell-induced neutrophil extracellular traps promote both hypercoagulability and cancer progression. PLOS ONE 2019, 14, e0216055. [CrossRef]

157. Lavoie, S.S.; Dumas, E.; Vulesevic, B.; Neagoe, P.-E.; White, M.; Sirois, M.G. Synthesis of Human Neutrophil Extracellular Traps Contributes to Angiopoietin-Mediated In Vitro Proinflammatory and Proangiogenic Activities. J. Immunol. 2018, 200, 3801-3813. [CrossRef] [PubMed]

158. Wislez, M.; Fujimoto, N.; Izzo, J.G.; Hanna, A.E.; Cody, D.D.; Langley, R.R.; Tang, H.; Burdick, M.D.; Sato, M.; Minna, J.D.; et al High Expression of Ligands for Chemokine Receptor CXCR2 in Alveolar Epithelial Neoplasia Induced by Oncogenic Kras. Cancer Res. 2006, 66, 4198-4207. [CrossRef]

159. Yuan, M.; Zhu, H.; Xu, J.; Zheng, Y.; Cao, X.; Liu, Q. Tumor-Derived CXCL1 Promotes Lung Cancer Growth via Recruitment of Tumor-Associated Neutrophils. J. Immunol. Res. 2016, 2016, 6530410. [CrossRef] [PubMed]

160. Yu, S.; Yi, M.; Xu, L.; Qin, S.; Li, A.; Wu, K. CXCL1 as an Unfavorable Prognosis Factor Negatively Regulated by DACH1 in Non-small Cell Lung Cancer. Front. Oncol. 2020, 9, 1515. [CrossRef]

161. Li, L.; Xu, L.; Yan, J.; Zhen, Z.-J.; Ji, Y.; Liu, C.-Q.; Lau, W.Y.; Zheng, L.; Xu, J. CXCR2-CXCL1 axis is correlated with neutrophil infiltration and predicts a poor prognosis in hepatocellular carcinoma. J. Exp. Clin. Cancer Res. 2015, 34, 129. [CrossRef]

162. López-Lago, M.A.; Posner, S.; Thodima, V.J.; Molina, A.M.; Motzer, R.J.; Chaganti, R.S.K. Neutrophil chemokines secreted by tumor cells mount a lung antimetastatic response during renal cell carcinoma progression. Oncogene 2013, 32, 1752-1760. [CrossRef]

163. Jaffer, T.; Ma, D. The emerging role of chemokine receptor CXCR2 in cancer progression. Transl. Cancer Res. 2016, 5, S616-S628. [CrossRef]

164. Keane, M.P.; Belperio, J.A.; Xue, Y.Y.; Burdick, M.D.; Strieter, R.M. Depletion of CXCR2 Inhibits Tumor Growth and Angiogenesis in a Murine Model of Lung Cancer. J. Immunol. 2004, 172, 2853-2860. [CrossRef]

165. Timaxian, C.; Vogel, C.F.A.; Orcel, C.; Vetter, D.; Durochat, C.; Chinal, C.; NGuyen, P.; Aknin, M.-L.; Mercier-Nomé, F.; Davy, M.; et al. Pivotal Role for Cxcr2 in Regulating Tumor-Associated Neutrophil in Breast Cancer. Cancers 2021, 13, 2584. [CrossRef] [PubMed]

166. Salmaggi, A.; Gelati, M.; Pollo, B.; Frigerio, S.; Eoli, M.; Silvani, A.; Broggi, G.; Ciusani, E.; Croci, D.; Boiardi, A.; et al. CXCL12 in Malignant Glial Tumors: A Possible Role in Angiogenesis and Cross-Talk between Endothelial and Tumoral Cells. J. Neuro-Oncol. 2004, 67, 305-317. [CrossRef] [PubMed]

167. Matsuo, Y.; Ochi, N.; Sawai, H.; Yasuda, A.; Takahashi, H.; Funahashi, H.; Takeyama, H.; Tong, Z.; Guha, S. CXCL8/IL-8 and CXCL12/SDF-1 $\alpha$ co-operatively promote invasiveness and angiogenesis in pancreatic cancer. Int. J. Cancer 2009, 124, 853-861. [CrossRef] [PubMed]

168. Tulotta, C.; Stefanescu, C.; Chen, Q.; Torraca, V.; Meijer, A.H.; Snaar-Jagalska, B.E. CXCR4 signaling regulates metastatic onset by controlling neutrophil motility and response to malignant cells. Sci. Rep. 2019, 9, 2399. [CrossRef]

169. Ibrahim, S.A.; Kulshrestha, A.; Katara, G.K.; Amin, M.A.; Beaman, K.D. Cancer derived peptide of vacuolar ATPase 'a2' isoform promotes neutrophil migration by autocrine secretion of IL-8. Sci. Rep. 2016, 6, 36865. [CrossRef] [PubMed]

170. Ibrahim, S.A.; Kulshrestha, A.; Katara, G.K.; Riehl, V.; Sahoo, M.; Beaman, K.D. Cancer-associated V-ATPase induces delayed apoptosis of protumorigenic neutrophils. Mol. Oncol. 2020, 14, 590-610. [CrossRef] [PubMed]

171. Ibrahim, S.A.; Katara, G.K.; Kulshrestha, A.; Jaiswal, M.K.; Amin, M.A.; Beaman, K.D. Breast cancer associated a2 isoform vacuolar ATPase immunomodulates neutrophils: Potential role in tumor progression. Oncotarget 2015, 6, 33033-33045. [CrossRef] [PubMed]

172. Sato, R.; Imamura, K.; Semba, T.; Tomita, Y.; Saeki, S.; Ikeda, K.; Komohara, Y.; Suzuki, M.; Sakagami, T.; Saya, H.; et al. TGF $\beta$ Signaling Activated by Cancer-Associated Fibroblasts Determines the Histological Signature of Lung Adenocarcinoma. Cancer Res. 2021, 81, 4751-4765. [CrossRef] [PubMed]

173. Palano, M.T.; Gallazzi, M.; Cucchiara, M.; De Lerma Barbaro, A.; Gallo, D.; Bassani, B.; Bruno, A.; Mortara, L. Neutrophil and Natural Killer Cell Interactions in Cancers: Dangerous Liaisons Instructing Immunosuppression and Angiogenesis. Vaccines 2021, 9, 1488. [CrossRef] [PubMed]

174. Ogura, K.; Sato-Matsushita, M.; Yamamoto, S.; Hori, T.; Sasahara, M.; Iwakura, Y.; Saiki, I.; Tahara, H.; Hayakawa, Y. NK Cells Control Tumor-Promoting Function of Neutrophils in Mice. Cancer Immunol. Res. 2018, 6, 348-357. [CrossRef] [PubMed]

175. Bueno, M.J.; Mouron, S.; Quintela-Fandino, M. Personalising and targeting antiangiogenic resistance: A complex and multifactorial approach. Br. J. Cancer 2017, 116, 1119-1125. [CrossRef] 
176. Schiffmann, L.M.; Fritsch, M.; Gebauer, F.; Günther, S.D.; Stair, N.R.; Seeger, J.M.; Thangarajah, F.; Dieplinger, G.; Bludau, M.; Alakus, H.; et al. Tumour-infiltrating neutrophils counteract anti-VEGF therapy in metastatic colorectal cancer. Br. J. Cancer 2019, 120, 69-78. [CrossRef]

177. Jung, K.; Heishi, T.; Incio, J.; Huang, Y.; Beech, E.Y.; Pinter, M.; Ho, W.W.; Kawaguchi, K.; Rahbari, N.N.; Chung, E.; et al. Targeting CXCR4-dependent immunosuppressive Ly6C low monocytes improves antiangiogenic therapy in colorectal cancer. Proc. Natl. Acad. Sci. USA 2017, 114, 10455-10460. [CrossRef]

178. Lee, W.S.; Yang, H.; Chon, H.J.; Kim, C. Combination of anti-angiogenic therapy and immune checkpoint blockade normalizes vascular-immune crosstalk to potentiate cancer immunity. Exp. Mol. Med. 2020, 52, 1475-1485. [CrossRef] [PubMed]

179. Furukawa, K.; Nagano, T.; Tachihara, M.; Yamamoto, M.; Nishimura, Y. Interaction between Immunotherapy and Antiangiogenic Therapy for Cancer. Molecules 2020, 25, 3900. [CrossRef] [PubMed]

180. Dahlman, J.E.; Barnes, C.; Khan, O.F.; Thiriot, A.; Jhunjunwala, S.; Shaw, T.E.; Xing, Y.; Sager, H.B.; Sahay, G.; Speciner, L.; et al. In vivo endothelial siRNA delivery using polymeric nanoparticles with low molecular weight. Nat. Nanotechnol. 2014, 9, 648-655. [CrossRef] [PubMed]

181. Miettinen, H.M.; Gripentrog, J.M.; Lord, C.I.; Nagy, J.O. CD177-mediated nanoparticle targeting of human and mouse neutrophils. PLoS ONE 2018, 13, e200444. [CrossRef] [PubMed] 